\title{
ACF INDUSTRIES
}

INCORPORATED

albugueraue division

ENGINEERING

This teport was preporice

sponsored by the Prepared as an account of work
the United Research and States nor the Government. Nerther their arch and Development the United States Nenther subcontraployees, nor any af mistration, nor any or warranty, express their employeir contractors habuity or respos or implied or as, makes any or usefulness of any for the accuracyes any legal

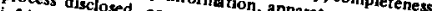

\section{PHOEBUS 2 CF / 2A PRESSURE VESSEL REDESIGNED MAIN CLOSURE STRUCTURAL PROOF TEST SPECIFICATION - PROCEDURE}

Prepared by:

H. T. Ried

Engineer

C. E Glavel

C. E. Arnold

Senior Engineer

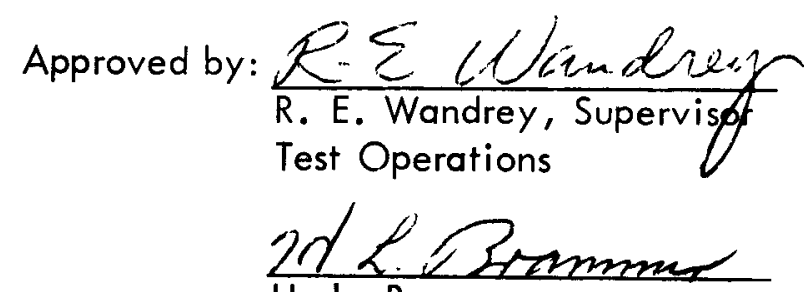

H. L. Brammer

Senior Project Engineer

Analytical Support Group

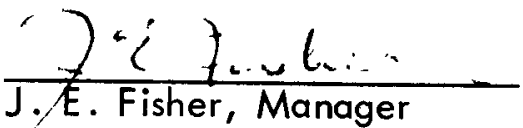

Mechanical Development

and Test Engineering 


\section{DISCLAIMER}

This report was prepared as an account of work sponsored by an agency of the United States Government. Neither the United States Government nor any agency Thereof, nor any of their employees, makes any warranty, express or implied, or assumes any legal liability or responsibility for the accuracy, completeness, or usefulness of any information, apparatus, product, or process disclosed, or represents that its use would not infringe privately owned rights. Reference herein to any specific commercial product, process, or service by trade name, trademark, manufacturer, or otherwise does not necessarily constitute or imply its endorsement, recommendation, or favoring by the United States Government or any agency thereof. The views and opinions of authors expressed herein do not necessarily state or reflect those of the United States Government or any agency thereof. 


\section{DISCLAIMER}

Portions of this document may be illegible in electronic image products. Images are produced from the best available original document. 


\section{DISTRIBUTION:}

W. W. Stagg, AEC-SAAO

S. A. Upson, AEC-ALO

W. J. Jackel

J. W. Neudecker, N-7, LASL (2)

A. Bond, J-9, LASL-NRDS

J.J. Beereboom, AGC-REON

D.J.Blevins, N-3, LASL

J. Cully, SNPO-A

F. P. Durham, N-DO, LASL

W. L . Kirk, N-DO, LASL

$D$. $F$. Lange, SNPO-C

A. A. Medeiros, SNPO-C

R . L . Murray, AGC-REON (3)

J.C. Rowley, N-7, LASL

R. W. Schroeder, SNPO-C (2)

C. H. Voit, NASA-WOO

V. L . Zeigner, N-3, LASL

C. R. Garr

J. E. Fisher

J.R. Stucki

R. W. Randolph

J. A. Kisner

H. L. Brammer

R. E. Wandrey

C. E. Arnold (2)

H. T. Ried (2)

R. E. Pozega

$R$. T . Johnson

Alameda Accountability Center (2)

Analytical Support Files (2) 


\section{TABLE OF CONTENTS}

Section

Title

INTRODUCTION

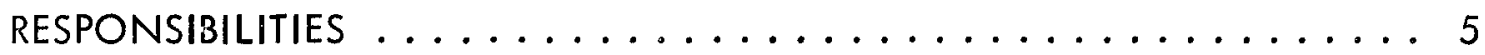

DETERMINATION OF LOADS $\ldots \ldots \ldots \ldots \ldots \ldots \ldots \ldots$

INSTRUMENTATION REQUIREMENTS $\ldots \ldots \ldots \ldots \ldots \ldots \ldots$

TEST PROCEDURE $\ldots \ldots \ldots \ldots \ldots \ldots \ldots \ldots \ldots \ldots \ldots$

Alternate Phase 1 Structural Test Loading Schedule . . . . . . . . . . . . 25

Figure

Phoebus $2 \mathrm{CF} / 2 \mathrm{~A}$ Structural Test Components . . . . . . . . . 6

Pressure Vessel Strain Gage Locations . . . . . . . . . . . . . 16

Strain Gage Locations on Nozzle Bolts . . . . . . . . . . . . . . 17

Pressure Vessel Main Closure Rotations and Deflections . . . . . . . . . . 20

Appendix 


\section{BLANK}




\section{INTRODUCTION}

1.1 This report specifies the requirements for conducting a structural test on the Phoebus $2 \mathrm{CF} / 2 \mathrm{~A}$ Pressure Vessel Redesigned Main Closure in conjunction with the Phoebus 2 Hydrostatic Test Nozzle. The Pressure Vessel was designed and fabricated by the Albuquerque Division of ACF Industries; the Nozzle was designed and fabricated by the REON Division of Aerojet General Corporation of Sacramento, California.

1.2 The test will be conducted in three phases. The First Phase is a hydrostatic structural proof test in which the test assembly will be loaded to simulate the $115 \%$ Nuclear Steady State load and extensive structural measurements will be made to determine the elastic behavior of the Main Closure. Internal loading will be simulated, where practical, through the use of differential pressure plenums designated $P_{1}, P_{2}, P_{3}$ and $P_{4}$, as shown in Figure 1 . No attempt will be made to simulate the thrust loads. No attempt will be made to simulate thermal loads as the testing will be performed under room temperature conditions. The loading condition was derived as shown in Phoebus 2 Interface Analysis - Part 1, Load Analys is, (Report Number P2-65-6, Rev. B). The Second Phase is a hydrostatic cycling test in which the test assembly will be loaded to simulate $100 \%$ of the Nuclear Steady State load for a total of ten cycles. Structural measurements will also be made during the test. The Third Phase will be conducted with the test assembly proof tested while chilled to liquid nitrogen temperatures at a loading which simulates the $100 \%$ Nuclear Steady State load. This test will more closely simulate the actual operational temperatures.

1.3 The test will be conducted during the month of January 1967 at the test facilities of the Albuquerque Division, ACF Industries, Incorporated.

\section{OBJECTIVES}

2.1 The primary objectives of the test are (1) to verify the structural analysis of the Phoebus 2 CF/2A Pressure Vessel Redesigned Main Closure and to ensure that structural compatibility exists between the Pressure Vessel and the Clamp, and (2) to prove the structural integrity of the design and evaluate the performance of the 7039 material under simulated operational temperatures.

\section{RESPONSIBILITIES}

3.1 H. T. Ried of Department 431 will actas Test Coordinator. Any requested changes or inquiries concerning the test should be directed to him. Deviations from this test specification must be approved by him or his designee. He is also responsible for arranging test schedules and informing interested parties of pertinent information concerning the test.

3.2 Department 411, Test Operations, will be responsible for conducting the test.

3.3 The Analytical Support Group of Department 431 will assist in evaluating the "raw" data during testing and will complete evaluation of the Pressure Vessel Redesigned Main Closure performance within six weeks after completion of testing. Los Alamos Scientific Laboratory, N-7 Division, will witness all testing and will determine when all test objectives have been accomplished. 


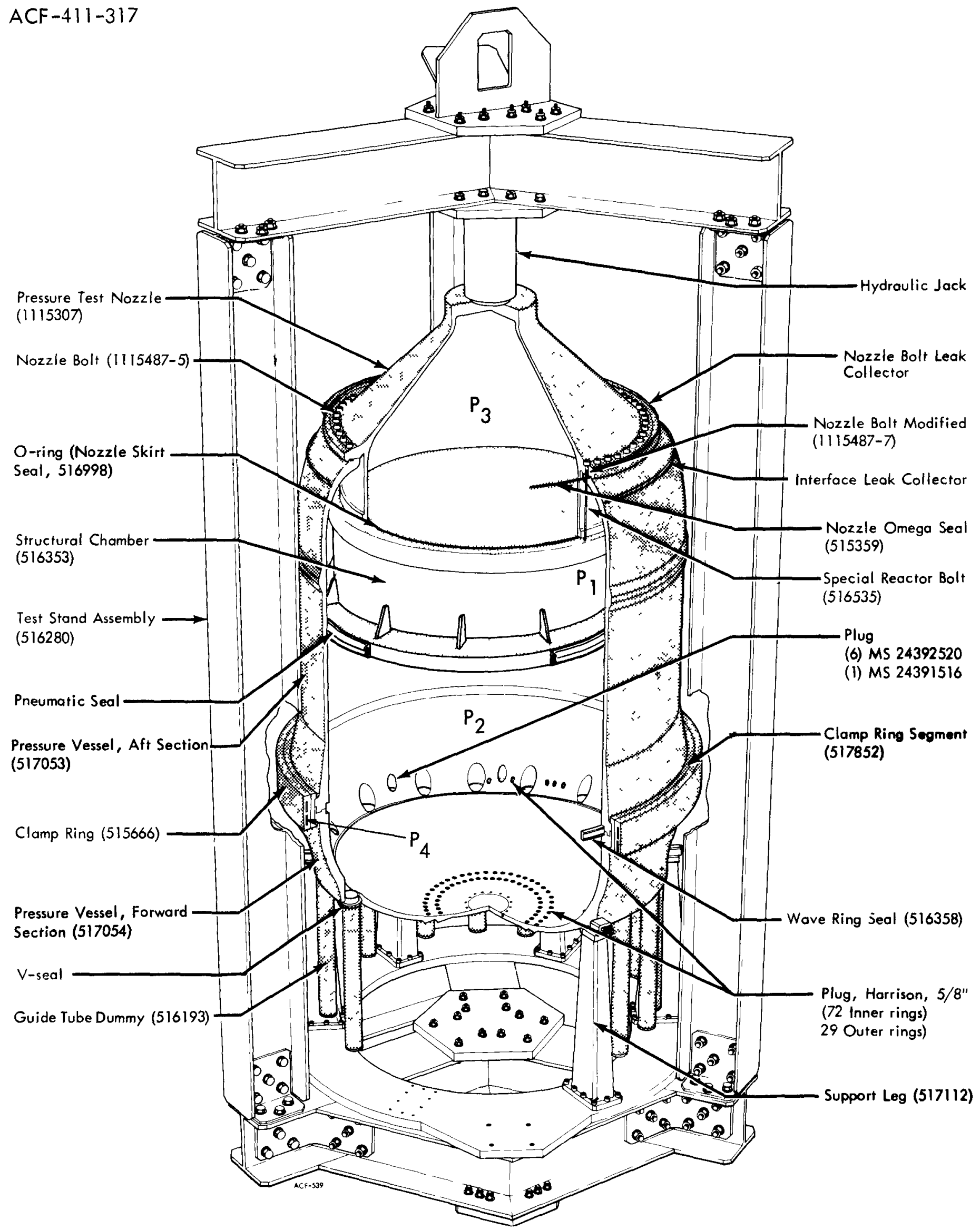

Fiqure 1. Phoebus $2 \mathrm{CF} / \angle \mathrm{A}$ Structural Test Components 


\section{DESCRIPTION OF TEST UNITS}

4.1 Listed below are the items required to conduct the test. Following the nomenclature of each item is the respective contractor's drawing number. The drawing number shall be the latest issue in effect. When more than one of an item is required, the quantity is shown in parentheses following the drawing number. Refer to Figure 1 for the assembly of the test components.

4.2 Aerojet General Corporation has provided the following Phoebus 2 test items:

(a) Pressure Test Nozzle, 1115307

(b) Nozzle Bolt, 1115487-5 (126)

(c) Nozzle Bolt-Modified, $1115487-7$ (18)

(d) Nozzle Bolt Seal (144)

4.3 ACF Department 431 will provide the following Phoebus 2 test items:

(a) Pressure Vessel Forward Section, 3-517054

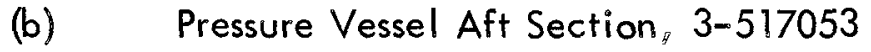

(c) Clamp Ring, 3-515666

(d) Clamp Ring Segment, 3-517852 (12)

(e) Guide Tube Dummy, 3-516193 (18)

(f) Nozzle Omega Seal, 3-515359

(g) Wave Ring Seal, 3-516358

(h) Support Leg, 3-516308 (6)

(i) $\quad \mathrm{V}$-seal, 6-556510 (18)

(i) Plug, 3-516289 (72)

(k) K-seal, 6-556490 (72)

(l) Structural Chamber, 3-516353

(m) Test Stand Assembly, 3-516280

(n) Lift Band, 3-516326

(o) Support Bolt, 3-516535 (18)

(p) Nozzle Skirt Seal, 3-516998

(q) Seal, Interplenum, P-2

\section{DETERMINATION OF LOADS}

\subsection{General}

The following calculations are made to determine the required static test pressures for the Phoebus $2 \mathrm{CF} / 2 \mathrm{~A}$ Vessel under the conditions of:

(a) 3 - Plenum Test - no thrust

(b) 2 - Plenum Test - no thrust (applies to both hydrostatic and cryogenic tests) 
The attempt is made to simulate nuclear steady state (NSS) loads and pressures wherever possible. However, the elimination of thrust from the test results in one or more pressures and/ or loads to be different from the NSS value. The correct NSS values, together with certain dimensions, are as described in Reference (1), below. Remaining dimensions are recorded in Reference (2).

\subsection{3-Plenum Test}

5.2.1 Using 100\% NSS values from Reference (1), determine total separating force in $\mathrm{P} . \mathrm{V}$. wall ( = FPV), treating the vessel as a free body:

$\mathrm{F}_{\mathrm{N}}=$ nozzle separating force $=1,511,608 \mathrm{lbs}$

$\mathrm{F}_{\mathrm{S}}=$ bolt $/$ core pre-load $=40,000 \mathrm{lbs}$.

$\mathrm{F}_{\mathrm{C}}=$ net core load on nozzle skirt (including $\left.F_{S}\right)=354,019 \mathrm{lbs}$.

$P_{1}=$ reflector inlet pressure $=842.3$ psig

$F_{P V}=F_{C}+F_{N}+P_{1} \pi\left(R_{V}{ }^{2}-R_{C}{ }^{2}\right)-F_{S}$

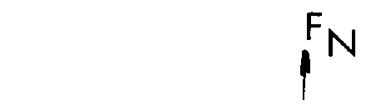

$=354,019+1,511,608+842.3\left(39.7425^{2}-30.45^{2}\right)-40,000$

$=354,019+1,511,608+1,725,995.2-40,000$

$F_{P V}=3,551,622 \mathrm{lbs}$, at $100 \%$ NSS condition.

then: For $115 \%$ NSS simulation:

$F_{P V}=1.15(3,551.622)=4,084,365$ lbs, at $115 \%$ NSS simulation and $P_{1}=1.15(842.3)=968.645$ psig at $115 \%$ NSS simulation.

5.2.2 Determine required test pressure $P_{2}$ in dome and lower cylinder section of vessel, such that $F_{P Y}$ at the main closure $=100 \%$ NSS, or $3,551,622$ pounds:

$F_{P V}=P_{2} \pi R_{V}{ }^{2}$
$P_{2}=\frac{F_{P V}}{\pi R_{V}{ }^{2}}$

$P_{2}=\frac{3,551,622}{\pi(39.7425)}=715.759$ psig $($ at $100 \%$ NSS simulation $)=\frac{715.759}{782.3}=$ $91 \%$ of NSS pressure at main closure.

and for $115 \%$ of NSS simulation:

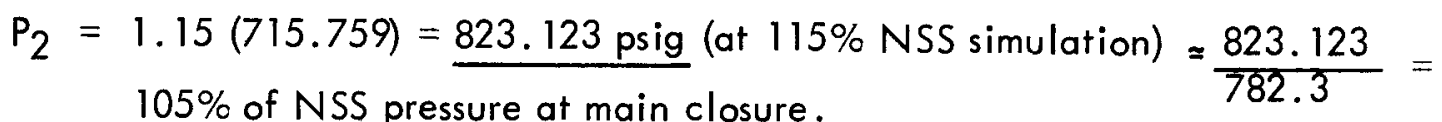

Reference (1) Rev. "B" (2-1-66) to "P2-65-6, Part 1- Load Analysis, Phoebus 2 Pressure Vessel/Nozzle Interface Analysis," dated March 26, 1965.

Reference (2) ACF Dwg. 3-517054-000, Rev. D - "P. V. Fwd. Section, C. F." ACF Dwg. 3-517053-000, Rev. E - "P. V. Aft Section, C. F." 
5.2.3 Determine $\mathrm{F}_{\mathrm{C}}$ core load obtained during test when $P_{1}, F_{P V}$, and $P_{3}$ are at required values for $100 \%$ NSS simulation:

then: $P_{1}=842.3$ psig

$P_{2}=715.759$ psig

$P_{3}=612.3$ psig $(\operatorname{Ref}(1))$

$F_{C}=P_{2} \pi R V^{2}+F_{S}-P_{1} \pi\left(R_{V}{ }^{2}-R_{C}{ }^{2}\right)-P_{3}$

$\pi R_{C}{ }^{2}=715.759 \pi(39.7425)^{2}+40,000-$

$842.3 \pi\left(39.7425^{2}-30.45^{2}\right)-612.3 \pi(30.45)^{2}$

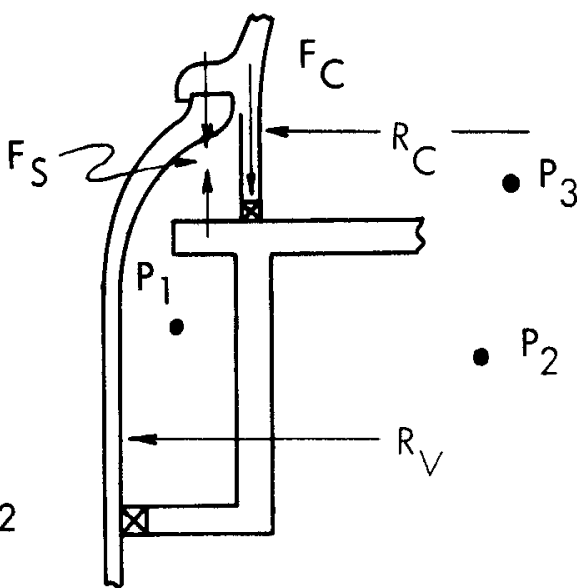

$F_{C}=3,551,622+40,000-1,725,995.2-1,783.562 .6$

$F_{C}=82,064.2 \mathrm{lbs} @ 100 \%$ NSS simulation $=82,064.2 / 354,019=23 \%$ of NSS value

For $115 \%$ of NSS simulation:

$F_{C}=(82,064-40,000)(1.15)+40,000=88,373.8$ lbs @115\% NSS simulation $=88,373.8 / 354,019=25 \%$ of NSS value

5.2.4 Determine $F_{1}$ nozzle interface load obtained during test when $P_{1}, F_{P V}$, and $P_{3}$ are at required values for $100 \%$ NSS simulation:

$F_{1}=F_{C}-F_{S}+P_{3} \pi R_{C}{ }^{2}+P_{1} \pi\left(R_{S}{ }^{2}-R_{C}{ }^{2}\right)$

$F_{I}=82,064-40,000+612.3 \pi(30.45)^{2}$

$+842.3 \pi\left(32.875^{2}-30.45^{2}\right)=82,064-$

$40,000+1,783,562.6+406,352.8$

$F_{1}=2,231,979 \mathrm{lbs}$ at $100 \%$ NSS simulation.

Per Ref. (1), $F_{1}$ at $100 \%$ NSS $=2,232,077$ lbs.

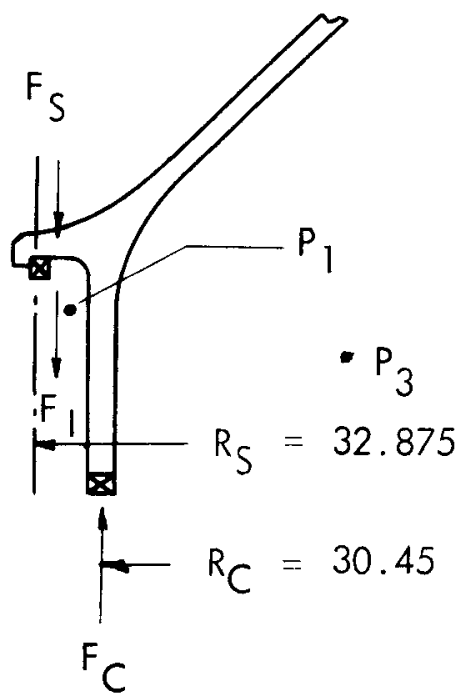

therefore, $F_{1}=100 \%$ NSS value at $100 \%$ NSS simulation.

For $115 \%$ NSS simulation:

$F_{1}=(2,231,979)(1.15)=2,566,776 \mathrm{lbs}=115 \%$ NSS value at $115 \%$ NSS simulation. 


\section{E.3 2-Plenum Test}

Hydrostatic

at $100 \%$ and $115 \%$ NSS simulation
Cryogenic

at $100 \%$ NSS simulation

5.3.1 In the 3-Plenum Test calculations of Paragraph 5.2, the 100\% NSS simulation was arbitrarily defined as when $P_{1}, F_{P V}$, and $P_{3}$ were at their true $100 \%$ NSS values; similarly for the $115 \%$ NSS simulation.

For the 2-Plenum Test, since $P_{1}=P_{2}$ at all conditions, then the \% NSS simulation will be defined as when $P_{1}$ and $P_{3}$ only are at their true $\%$ NSS values.

FPV at $100 \%$ NSS simulation:

$P_{2}=P_{1}=842.3$ psig

$F_{P V}=842.3 \pi(39.7425)^{2}=4,179,523 \mathrm{lbs}=4,179,523 / 3,551,622=\underline{118 \%}$ NSS value at $100 \%$ simulation.

at $115 \%$ NSS simulation:

$P_{2}=P_{1}=(842.3)(1.15)=968.645$ psig

$F_{P V}=968.6 \pi(39.7425)^{2}=4,806,451 \mathrm{lbs}=135 \%$ NSS value at $115 \%$ simulation.

5.3.2 Determine $F_{C}$ (See sketch in Paragraph 5.2.3). This equarion simplifies to:

$F_{C}=\left(P_{2}-P_{3}\right) \quad R_{C}^{2}+40,000$

at $100 \%$ NSS simulation:

$F_{C}=(842.3-612.3) \pi(30.45)^{2}+40,000$

$F_{C}=709,964.7 \mathrm{lbs}$ at $100 \%$ NSS simulation $=201 \%$ NSS value at $100 \%$ NSS simulation.

at $115 \%$ NSS simulation:

$P_{2}=P_{1}=968.645$ psig

$P_{3}=612.3(1.15)=704.145 \mathrm{psig}$

$F_{C}=(968.645-704.145) \pi(30.45)^{2}+40,000=810,459 \mathrm{lbs}$ at $115 \%$ NSS simulation $=229 \%$ NSS value at $115 \%$ NSS simulation. 
5.3.3 Determine $F_{1}$ (See sketch in Paragraph 5.2.4)。 Since $P_{1}=P_{2}$, the equation simplifies to:

$F_{1}=P_{1} \pi R_{S}^{2}$

at $100 \%$ NSS simulation:

$F_{1}=842.3 \pi(32.875)^{2}=2,859,880$ lbs at $100 \%$ NSS simulation $=2,859,880 /$ $2,232,077=128 \%$ NSS value at $100 \%$ NSS simulation.

at $115 \%$ NSS simulation:

$F_{I}=(2,859,880)(1.15)=3,288,862$ Ibs at $115 \%$ NSS simulation $=3,288,862 /$ $2,232,077=147 \%$ NSS value at $115 \%$ NSS simulation.

\subsection{Summary}

Following is a summary of loads and pressures. Values are rounded off to the nearest whole number.

\begin{tabular}{|c|c|c|c|c|c|}
\hline \multirow{2}{*}{ Test Condition } & \multirow{2}{*}{$\begin{array}{c}\text { Pressure or } \\
\text { Load }\end{array}$} & \multicolumn{2}{|c|}{ @100\% NSS Simulation } & \multicolumn{2}{|c|}{ @115\% NSS Simulation } \\
\hline & & Test Value & $\begin{array}{c}\% \text { True } \\
\text { NSS Value }\end{array}$ & Test Value & $\begin{array}{c}\% \text { True } \\
\text { NSS Value }\end{array}$ \\
\hline \multirow{7}{*}{$\begin{array}{l}\quad 3 \\
\text { Plenum } \\
\text { Hydrostatic } \\
\text { Test }\end{array}$} & $P_{1}$ (psig) & 842 & 100 & 969 & 115 \\
\hline & $P_{2}$ (psig) & 716 & $\sim 91$ & 823 & $\sim 105$ \\
\hline & $P_{3}$ (psig) & 612 & 100 & 704 & 115 \\
\hline & $F_{P V}$ (lbs) & $3,551,622$ & 100 & $4,084,365$ & 115 \\
\hline & $\mathrm{Fc}$ (lbs) & 82,064 & 23 & 88,374 & 25 \\
\hline & $F_{1}$ (lbs) & $2,231,979$ & 100 & $2,566,776$ & 115 \\
\hline & Thrust & 0 & 0 & 0 & 0 \\
\hline \multirow{7}{*}{$\begin{array}{l}\quad 2 \\
\text { Plenum } \\
\text { Hydrostatic } \\
\quad \text { or } \\
\text { Cryogenic } \\
\text { Test }\end{array}$} & $P_{1}$ (psig) & 842 & 100 & 969 & 115 \\
\hline & $P_{2}$ (psig) & 842 & $\sim 108$ & 969 & $\sim 124$ \\
\hline & $P_{3}$ (psig) & 612 & 100 & 704 & 115 \\
\hline & FPV (lbs) & $4,179,523$ & 118 & $4,806,451$ & 135 \\
\hline & $\mathrm{FC}_{\mathrm{C}}(\mathrm{lbs})$ & 709,965 & 201 & 801,459 & 229 \\
\hline & $F_{1}$ (lbs) & $2,859,880$ & 128 & $3,288,862$ & 147 \\
\hline & Thrust & 0 & 0 & 0 & 0 \\
\hline
\end{tabular}




\section{BLANK}

i 


\section{INSTRUMENTATION REQUIREMENTS}

\subsection{Strains}

6.1.1 Foil-type electrical resistance strain gages capable of indicating strains to 0.005000 inch-per-inch shall be installed as shown in Figures 2 through 4 . All dimensions given in the figures are in inches. For two gage rosettes, low-numbered gages are circumferential, and high-numbered gages are axial unless otherwise noted. For three gage rosettes, the lowest numbered gage will be considered circumferential and the highest numbered gage axial. When a two gage rosette is specified, one gage axis is to be located in the circumferential (hoop) direction with respect to the vessel and the second gage axis (axial) is perpendicular to the first. Strain gage positional tolerance will be $\pm 0,060 "$ (axially and circumferentially). Gage lengths shall be 0.250 " maximum unless otherwise noted.

6.1.2 Four of the nozzle bolts shall be instrumented with strain gages to give tensile and bending loads. Each bolt shall have four axial straingages bonded at quadrants on the bolt shanks. The instrumentedbolts shall be calibrated (load versus strain) prior to use in the testing. The bolt gages shall be numbered B 1 through B16.

\subsection{Deflection and Rotation}

6.2.1 Any laboratory type instrument capable of measuring deflections within 0.001 inch maybe used. Suggested types are: dial indicators, ACF-designed strain gage linear transducers, LVDT'S, and autocollimators. The required measurements for deflections and rotations of the Nozzle and Pressure Vessel are shown in Figures 5 and 6.

\subsection{Pressures}

Bourdon tube-type pressure gages and/or transducers may be used. The instruments must have a repeatable accuracy of $\pm 0.5 \%$ of reading. Differential pressure tolerances must be maintained within \pm 2.0 psi except for the Clamp Ring ( $\left.P_{4}\right)$ plenum which may vary \pm 30 psi. All instruments must be certified prior to testing without intervening usage.

\section{TEST PROCEDURE}

\subsection{Unit Assembly}

The assemblyprocedure described in this section is based on previous Pressure Vessel-Nozzle tests. Alternate assembly techniques may be used when they are considered more feasible. The test units will be visually inspected prior to assembly. All seal grooves and sealing surfaces must be cleaned prior to instaliing the seals. Install coffer dams or seal leakage collectors (such as those shown in Figure I) on the test units. The purpose of the individual collector is to differentiate between sources of any leakage. All seals except the Nozzle and Wave Ring Seals (3-515359 and 3-516358, respectively) shall be lightly coated with Dow Corning No. 11 Silicone grease prior to insta? lation. 
A member of the Analytical Support Group, Department 431, must be present during all assembly operations. Assemble the unit of testing as follows:

(a) Mount strain gages to Pressure Vessel and components as shown in Figures 2 through 4 and the Instrumentation List, Appendix A. Data will be recorded on Gilmore Recorders.

(b) Mount six Support Leg Assemblies and Spacers to Mounting Ring. Torque bolts to 80 ft-lbs.

(c) Center Pressure Vessel Forward Section on the six Support Legs. Torque leg dogs to 20 ft-lbs.

(d) Plug all holes in the Pressure Vessel Forward Section (Dome) with K-seals and plugs specified in Figure 1. Torque plugs to $60 \mathrm{ft}$-lbs.

(e) Install 18 Dummy Guide Tubes with metal V-seals into Forward Section of Pressure Vessel. A torque of $60 \mathrm{in}$-lbs is required.

(f) Make the required dimensional checks on the Seals, Nozzle, and Vessel as follows:

(1) Shear Lip. The following physical dimensions of the Aft Section and Nozzle are required before and after the testing at $0,90,180$, and $270^{\circ}$ :

(a) ID of the Nozzle Shear Lip at Station 68.5

(b) OD of the Pressure Vessel at Station 68.5

NOTE: Reference marks should be marked on the test units to ensure that dimensional measurements are made at the same locations.

(2) Wave Ring Seal. Measure the OD of each lobe before assembly. After inserting the Seal in the Pressure Vessel Forward Section Groove, measure the exposed or top OD of the lobe. Upon completion of the structural test, measure both lobe OD's after removal from the Pressure Vessel. Mark orientation as to the forward and aft lobe with respect to the Pressure Vessel.

(3) Omega Seal. After testing, measure the height of the Seal, i.e., from lobe to Tobe and the gap between the legs.

(4) Pressure Vessel Aft Section Seal Groove. Measure the depth of the seal groove at eight (8) equally-spaced locations beginning at $0^{\circ}$.

(5) Test Assembly. Dye penetrant check all welds and highly stressed areas prior to and after testing. These inspections must be witnessed by Department 431 personnel.

(6) Clamp Segments. A visual inspection will be performed by Department 431 personnel on each clamp segment and its specific mating location on the Pressure Vessel before final assembly. 
(g) Install Wave Ring Seal into the Pressure Vessel Forward Section.

(h) Assemble Pneumatic Seal to Pressure Vessel Aft Section with six seal clamps. Instal! Seal Clamps, taking care that seal has no wavers or puckers when tightening screws.

(i) Center Structural Chamber on wooden guide rack.

(i) Attach Lifting Band and lower Pressure Vessel Aft Section over Structural Chamber taking care not to damage Pneumatic Seal or Seal Clamps. Adjust section radially for proper angular orientation with Structural Chamber.

(k) Install O-ring in Structural Chamber.

(I) Install Nozzle Omega Seal in Pressure Vessel Aft Section.

(m) Position Nozzle over Pressure Vessel Assembly. Angularly orientate Nozzle with respect to Pressure Vessel and Structural Chamber Assemblies and lower into position.

(n) Install modified nozzle bolts with $\mathrm{K}$-seals.

(o) Install nozzle bolts with $K$-seals so that the four instrumented bolts are $90^{\circ}$ apart. See Figure 3 and Appendix A. Torque all nozzle bolts to a preload of 34,000 pounds in diametrically opposed pairs.

(p) Assemble 18 supportbolts with K-seals through special nozzle bolts to support Structural Chamber. Torque support bolts to $15 \mathrm{ft}$-lbs (equivalent to $40,000 \mathrm{lbs}$, total load).

(q) Install internal gap deflection gages as shown in Figure 6.

(r) Center Pressure Vessel Aft Section - Nozzle Assembly over Dome and lower down around Wave Ring Seal.

(s) Ensure that the mating surfaces between the pressure vessel and the clamp segments are clean and unlubricated. Install the 12 Clamp Ring Segmentsstarting at $0^{\circ}$. Pull the Clamp Ring into position, and measure the load required.

(t) Install Nozzle Bolt Leak Collector as shown in Figure 1.

(u) Fill the Clamp Ring $\left(P_{4}\right)$, Nozzle $\left(P_{3}\right)$, Structural Chamber Annulus $\left(P_{1}\right)$, and Forward Section $\left(P_{2}\right)$ with softened water taking care that all air is bled from the vessel.

(v) Install deflection gages as shown in Figures 5 and 6, and make connection to the Gilmore Recorder per the Instrumentation List, Appendix A.

(w) Connect the pressurization system as shown in Figure 7.

(x) Install hydraulic jack as shown in Figure 1 . 


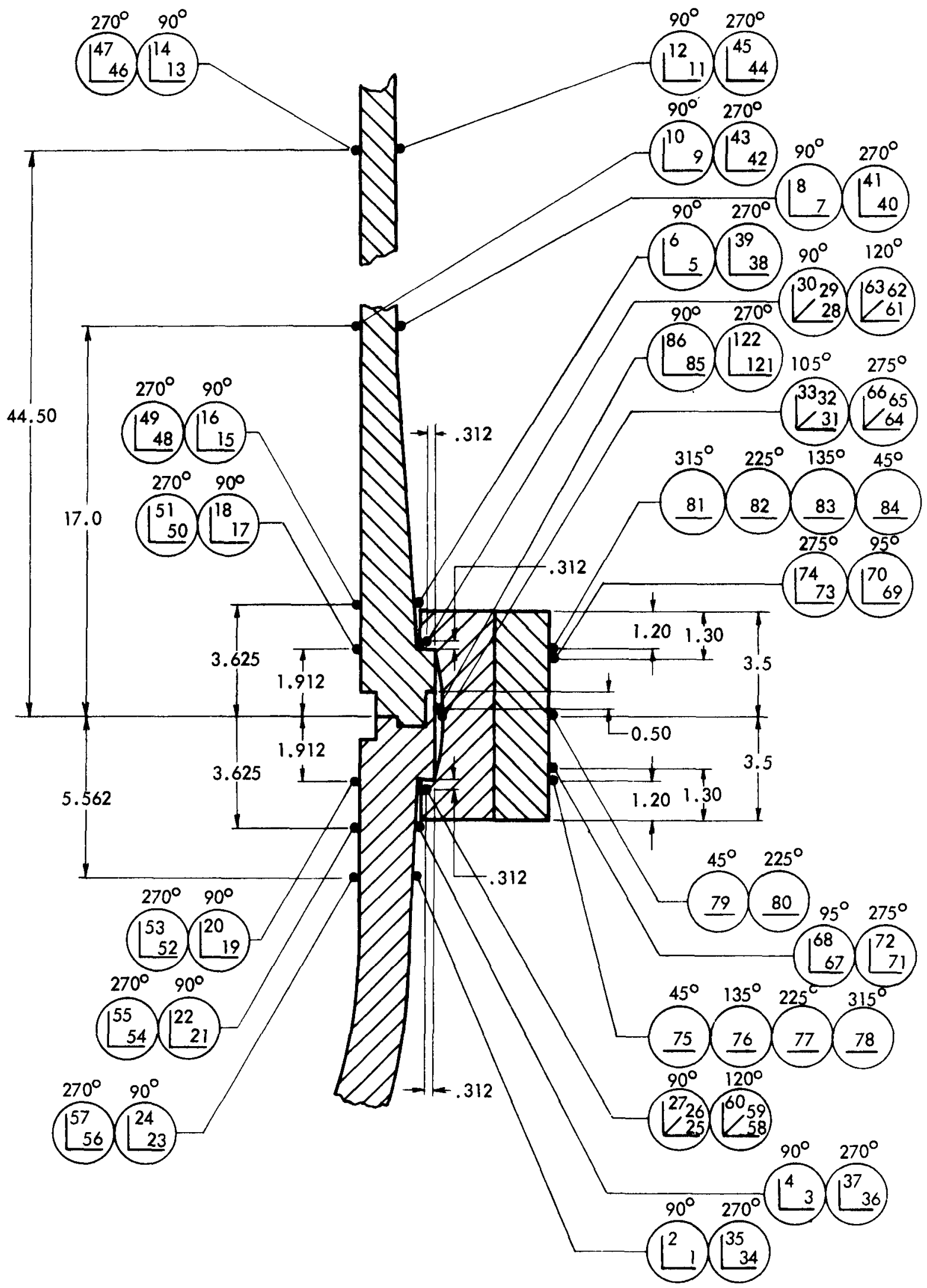

Figure 2. Pressure Vessel Strain Gage Locations 
Strain Gage Lead Wire \#30 Gage Insulated Typical - 4 Places

Drill 3/32 Through

Fill all Cavities with Sealing Compound

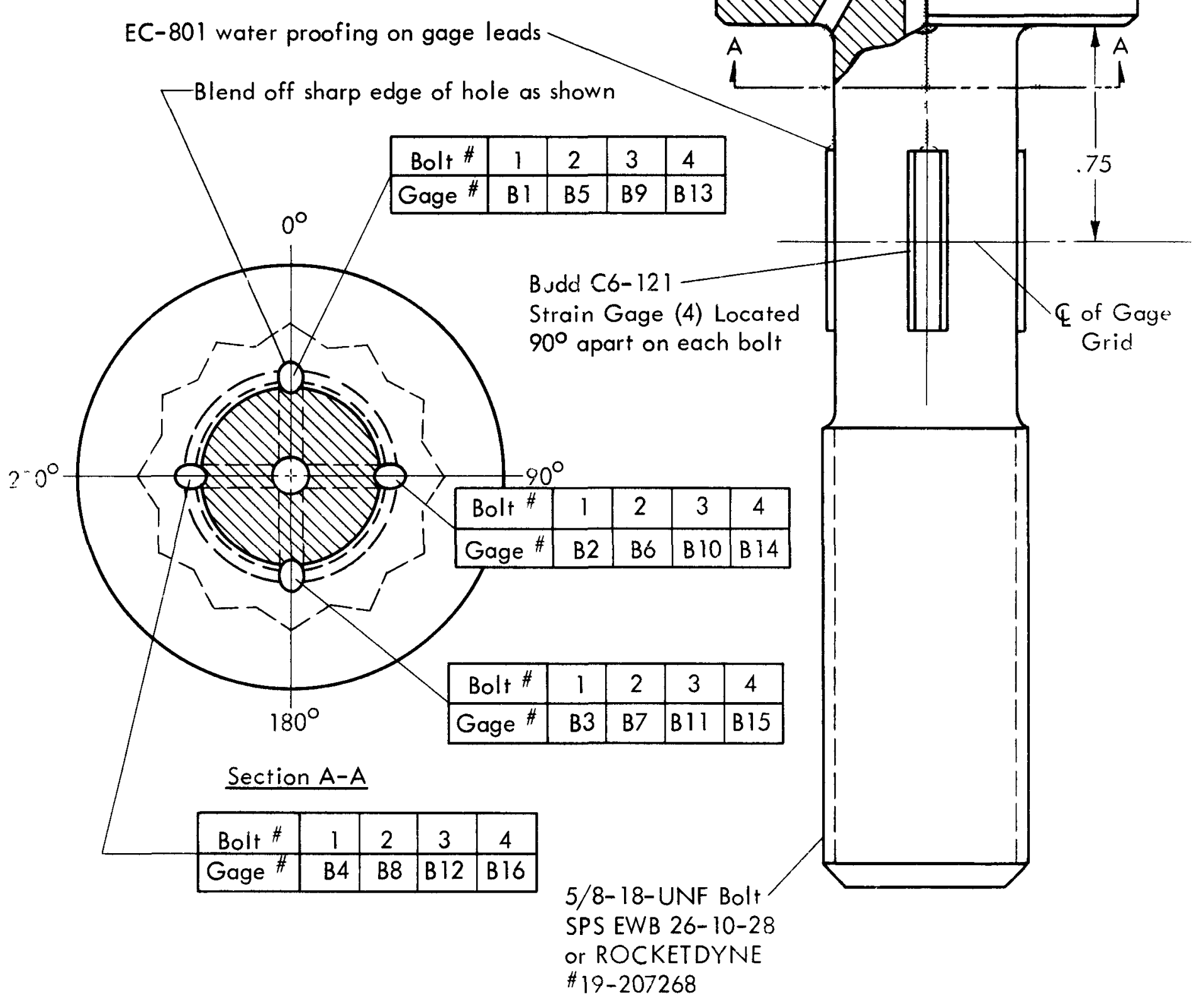

Figure $\therefore$ Strain Gage Locations on Nozzle Bolts 
$A C F-411-317$

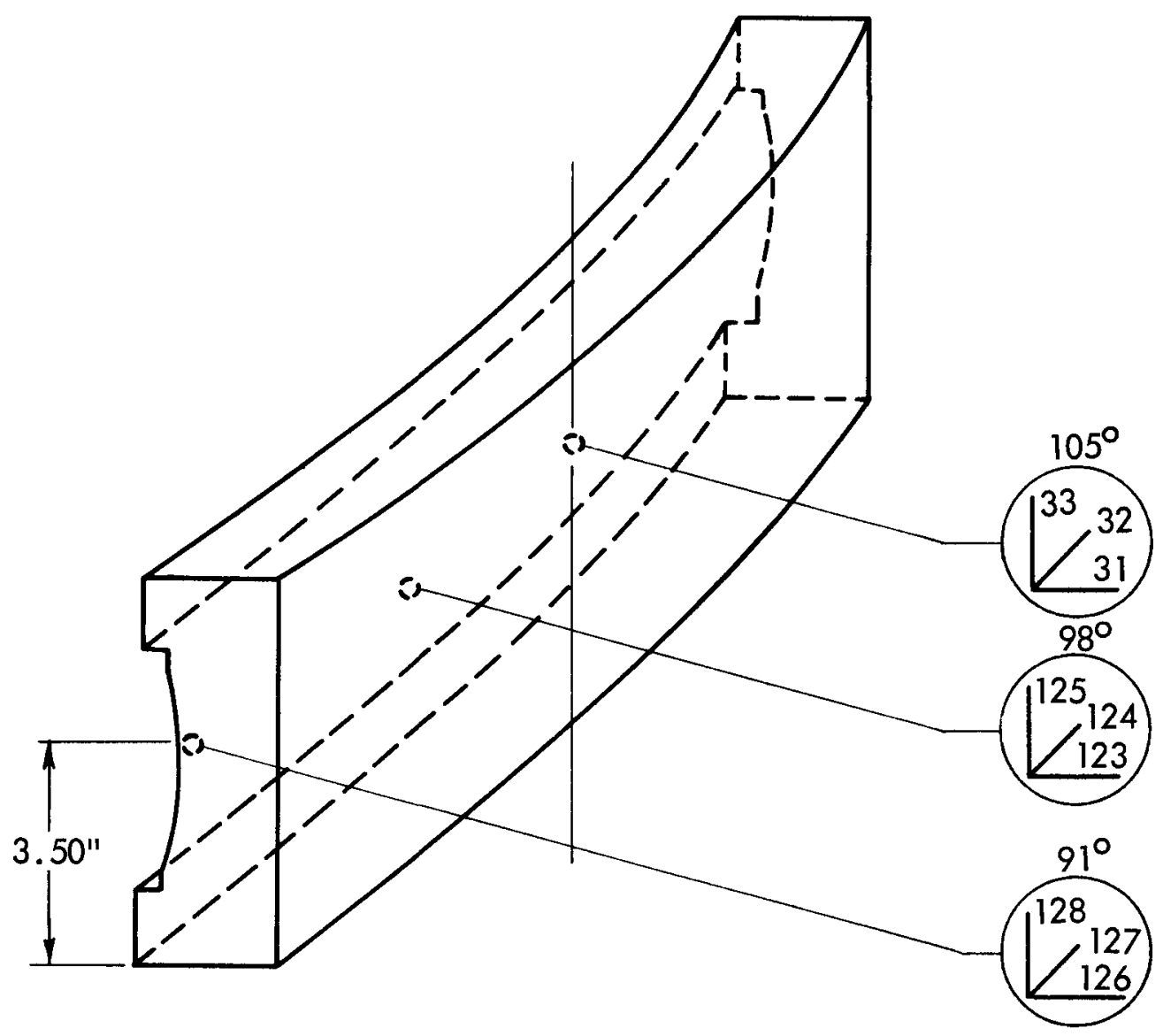

NOTE: All strain gages to be placed on inside surface of Segment ${ }^{4}$.

Figure 4. Strain Gage Locations on Clamp Segment 


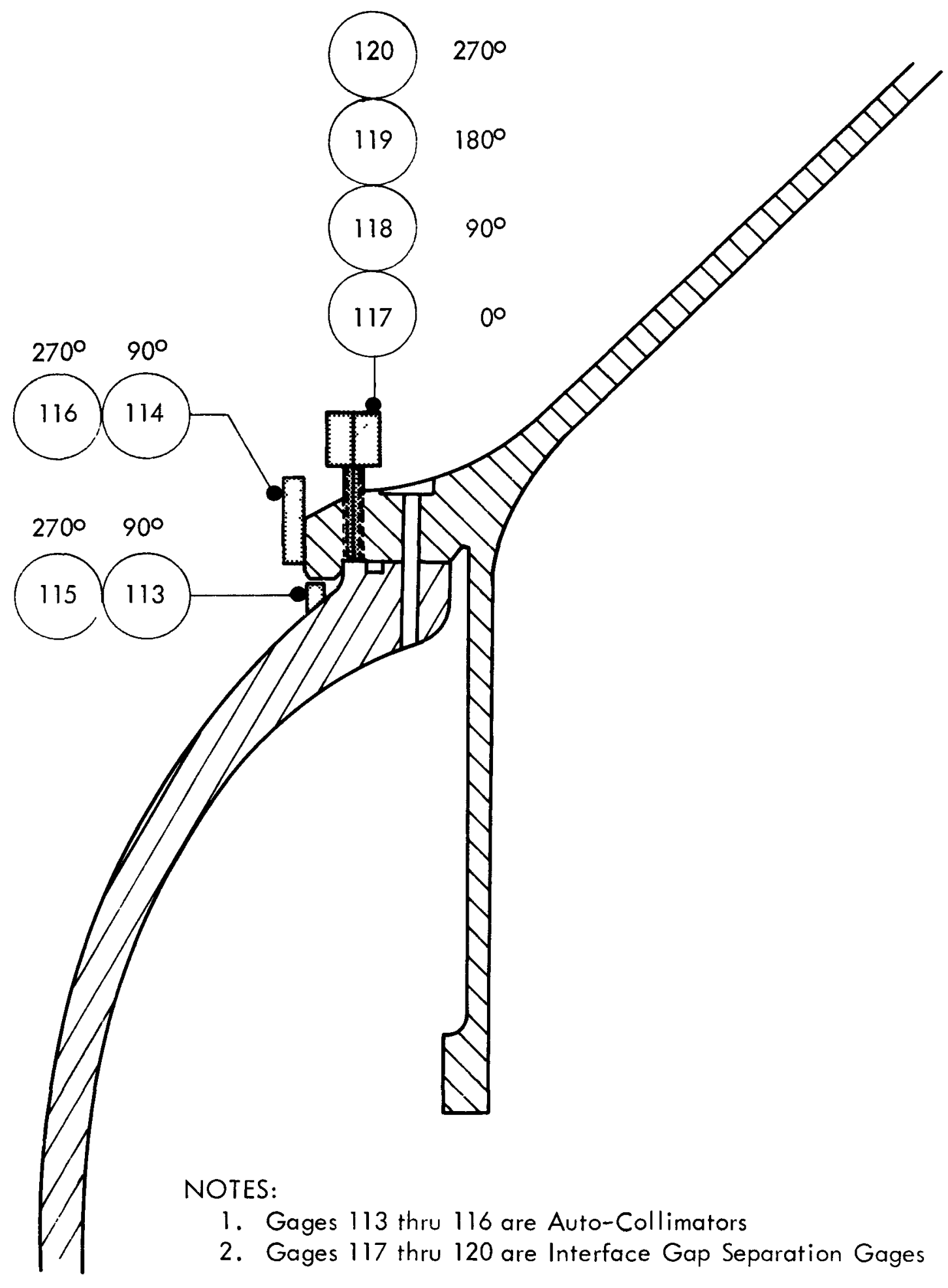

Figure 5. Interface Rotations and Gap Separations 


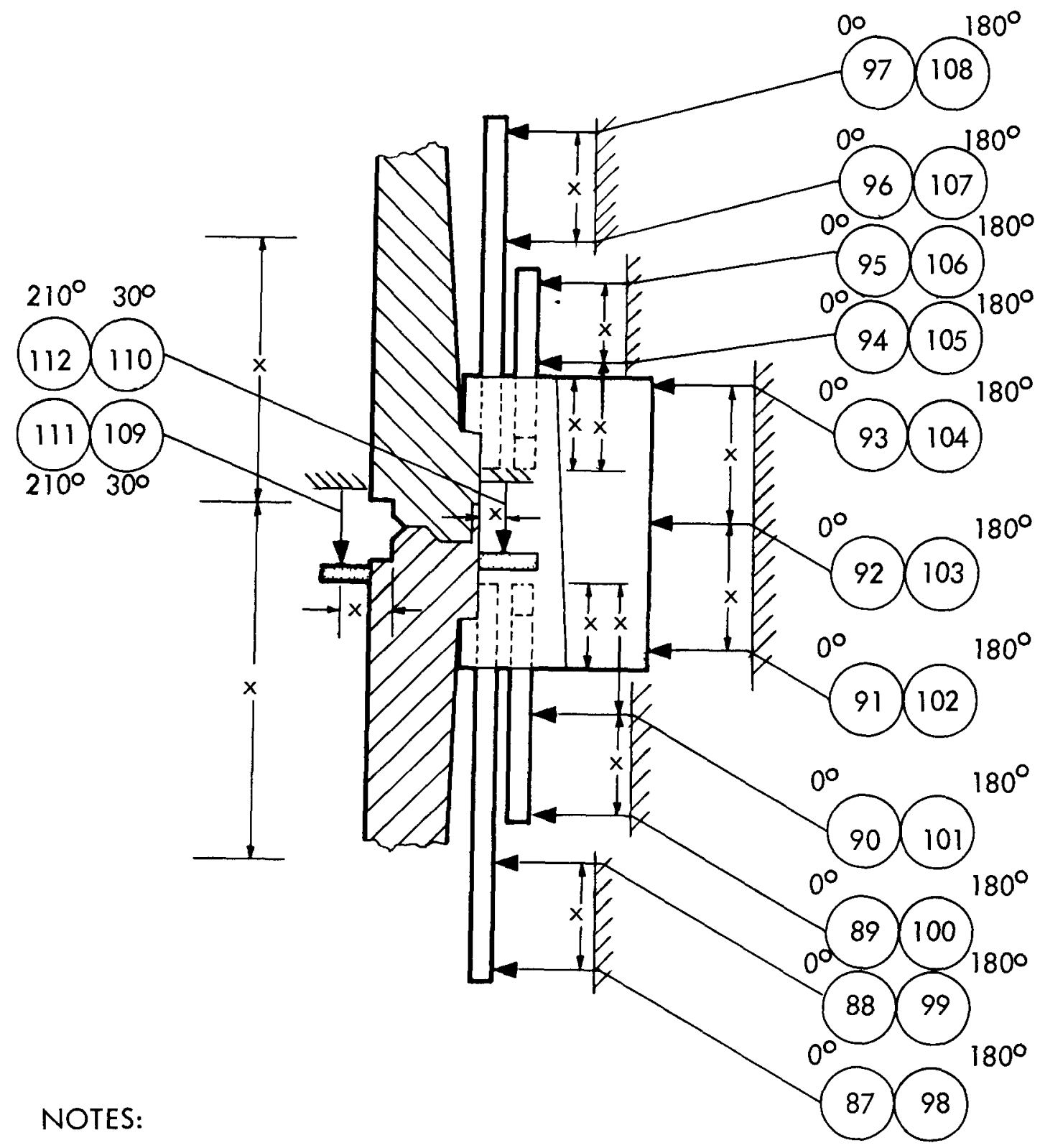

1. Dimensions indicated are to be measured within \pm 0.010 inch.

2. Radial growth of vessel to have positive indication of output.

3. Gap gages to have positive indication from gap opening.

Figure 6. Pressure Vessel Main Closure Rotations and Deflections 


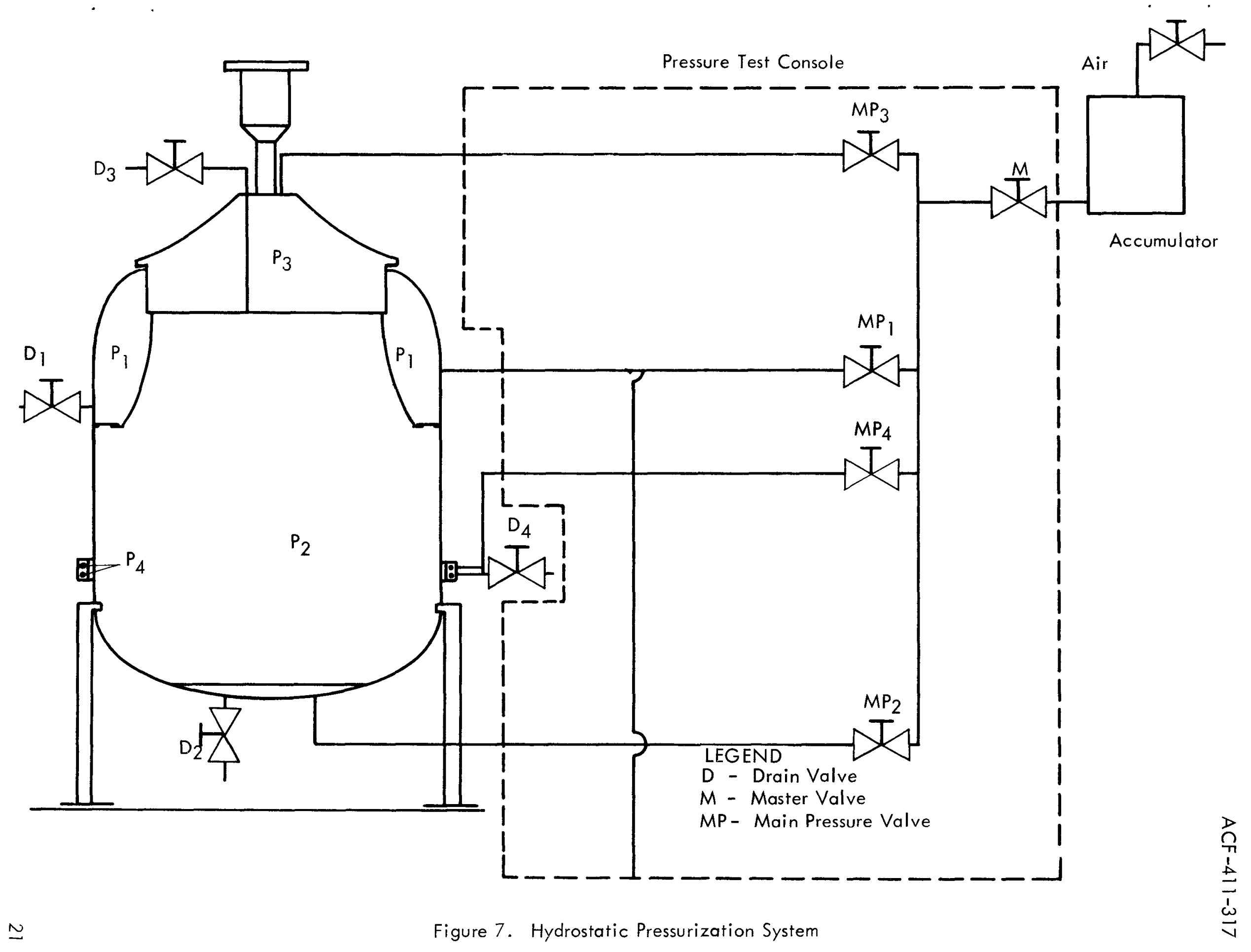




\subsection{Phase 1 - Hydrostatic Structural Test}

7.2.1 Apply approximately 10 psig to the hydraul ${ }^{\circ} \mathrm{c}$ jack to stabilize the Pressure Vessel Assembly.

7.2.2 Apply pressure in stepped increments and release after each application as shown in Table 1. Maintain the jack load as specified by Paragraph 7.2.1. In agreement with a memorandum ${ }^{1}$ from $\mathrm{J}$. W. Neudecker to J. R. Stucki the hydrostatic pressure test will be scheduled as follows: The three plenum test setup is much preferred over the two plenum arrangement. However, since the time available for conducting the test is extremely limited, the two plenum test setup should be selected without delay in the event that trouble is encountered in effecting a seal with the three plenum arrangement. The two plenum test setup will be run utilizing Table 2 loading schedule. After exercising the instrumentation (initial $30 \%$ pressure steps), re-zero the instrumentation. To maintain a complete computerized datahistory of the Phase 1 and 2 tests, the recorders shall not be zeroed after this point. Record the data at each pressure increment.

NOTE: If an interruption occurs, testing will resume with the initial zero load being the starting point.

7.2.3 Record the data from the instrumentation at each increment of pressure.

7.2.4 After the Phase 1 testing has been completed, verify the documentation on locations of all deflection gages and visually inspect the Pressure Vessel Assembly for evidence of deformation.

\subsection{Phase 2 - Hydrostatic Structural Proof Test}

7.3.1 Install additional instrumentation, if determined necessary. The type and location will be specified by Department 431 , depending upon test results.

7.3.2 Assemble the Pressure Vessel and Test System as described in Paragraph 7.1(b) through $(x)$ on pages 14 and 15 .

7.3.3 Make dimensional checks to insure that the Nozzle is completely secied on the Pressure Vessel.

7.3.4 Apply approximately 10 psig to the hydraulic jack to stabilize the Pressure Vessel Assembly. Apply pressure in stepped increments as shown in Table 3. Alternate two-chamber test is shown in Table 4. Record the data at each pressure increment. Repeat the above procedure for a minimum of ten pressure cycles.

NOTE: If an interruption occurs, testing will resume with the initial zero load being the starting point.

7.3.5 Drain, disassemble, and dry Pressure Vessel Assembly. Record the nozzle bolt breakaway torque values and the final strain indications. Obtain the required dimensional measurements as stated in Paragraph $7.1(\mathrm{f})$, Items 1 through 4 (page 14).

7.3.6 Visually inspect the Pressure Vessel Assembly for evidence of deformation. Dye penetrant inspect weld areas.

'Memorandum trom J.W. Neudecker to J.R. Stucki, titled Proof Test Pressures, Phoebus 2 Pressure Vessel Proof Test. 
Table 1. Phase 1 Structural Test Loading Schedule

\begin{tabular}{|c|c|r|r|r|r||c|c|c|c|c|c|}
\hline \multirow{2}{*}{ Step } & Load & $P_{1}$ & $P_{2}$ & $P_{3}$ & $P_{4}$ & & Load & $P_{1}$ & $P_{2}$ & $P_{3}$ & $P_{4}$ \\
\hline & $\%$ & psig & psig & psig & psig & Step & $\%$ & psig & psig & psig & psig \\
\hline $0 *$ & $0 *$ & 0 & 0 & 0 & 0 & 20 & $10^{*}$ & & & & 126 \\
\hline 1 & & 253 & 253 & 253 & & 21 & & & 84 & & \\
\hline 2 & & & & 184 & & 22 & & & & 84 & \\
\hline 3 & & & 215 & & & 23 & & 168 & 168 & 168 & \\
\hline 4 & $30 *$ & & & & 378 & 24 & & & & 122 & \\
\hline 5 & & & 253 & & & 25 & & & 143 & & \\
\hline 6 & & & & 253 & & 26 & $20 *$ & & & & 252 \\
\hline 7 & & 0 & 0 & 0 & & 27 & & & 168 & & \\
\hline 8 & $0 *$ & & & & 0 & 28 & & & & 168 & \\
\hline 9 & & 253 & 253 & 253 & & 29 & & 253 & 253 & 253 & \\
\hline 10 & & & & 184 & & 30 & & & & 184 & \\
\hline 11 & & & 215 & & & 31 & & & 215 & & \\
\hline 12 & $30 *$ & & & & 378 & 32 & $30 *$ & & & & 378 \\
\hline 13 & & & 253 & & & 33 & & & 253 & & \\
\hline 14 & & & & 253 & & 34 & & & & 253 & \\
\hline 15 & & 0 & 0 & 0 & & 35 & & 0 & 0 & 0 & \\
\hline 16 & $0 *$ & & & & 0 & 36 & $0 *$ & & & & 0 \\
\hline 17 & & 84 & 84 & 84 & & 37 & & 421 & 421 & 421 & \\
\hline 18 & & & & 61 & & 38 & & & & 306 & \\
\hline 19 & & & 72 & & & 39 & & & 358 & & \\
\hline$*$ Record Instrumentation & & & & & & & & & \\
\hline
\end{tabular}


Table I. Phase I Structural Test Loading Schedule (Continued)

\begin{tabular}{|c|c|c|c|c|c|c|c|c|c|c|c|}
\hline Sten & Load & $\mathrm{P}_{1}$ & $P_{2}$ & $P_{3}$ & $P_{4}$ & Step & Load & $\mathrm{P}_{1}$ & $P_{2}$ & $P_{3}$ & $P_{4}$ \\
\hline step & $\%$ & psig & psig & psig & psig & & $\%$ & psig & psig & psig & psig \\
\hline 40 & $50 *$ & & & & 630 & 60 & & & & 612 & \\
\hline 41 & & & 420 & & & 61 & $100 *$ & & & & 1260 \\
\hline 42 & & 505 & & & & 62 & & & 788 & & \\
\hline 43 & & & & 367 & & 63 & & 926 & & & \\
\hline 44 & & & 430 & & & 64 & & & & 673 & \\
\hline 45 & $60 *$ & & & & 756 & 65 & $110^{*}$ & & & & 1386 \\
\hline 46 & & & 501 & & & 66 & & & 823 & & \\
\hline 47 & & 589 & & & & 67 & & 969 & & & \\
\hline 48 & & & & 428 & & 68 & & & & 704 & \\
\hline 49 & $70 *$ & & & & 882 & 69 & $115^{*}$ & & & & 1449 \\
\hline 50 & & & 573 & & & 70 & & 840 & & & \\
\hline 51 & & 674 & & & & 71 & & & 760 & & \\
\hline 52 & & & & 490 & & 72 & & & & 600 & \\
\hline 53 & $80 *$ & & & & 1008 & 73 & & & 704 & & \\
\hline 54 & & & 644 & & & 74 & & 704 & & & \\
\hline 55 & & 758 & & & & 75 & & & & 704 & \\
\hline 56 & & & & 551 & & 76 & & 0 & 0 & 0 & \\
\hline 57 & $90 *$ & & & & 1134 & 77 & 0 * & & & & 0 \\
\hline 58 & & & 716 & & & & & & & & \\
\hline 59 & & 842 & & & & & & & & & \\
\hline
\end{tabular}


Table 2. Alternate Phase 1 Structural Test Loading Schedule

\begin{tabular}{|c|c|c|c|c||c|c|c|c|c|}
\hline \multirow{2}{*}{ Step } & Load & $\mathrm{P}_{1} \mathrm{P}_{2}$ & $\mathrm{P}_{3}$ & $\mathrm{P}_{4}$ & $\mathrm{~F}$ & Load & $\mathrm{P}_{1}=\mathrm{P}_{2}$ & $\mathrm{P}_{3}$ & $\mathrm{P}_{4}$ \\
\hline & $\%$ & $\mathrm{psig}$ & $\mathrm{psig}$ & $\mathrm{psig}$ & Step & $\%$ & $\mathrm{psig}$ & $\mathrm{psig}$ & $\mathrm{psig}$ \\
\hline $0^{*}$ & $0^{*}$ & 0 & 0 & 0 & 20 & & & 168 & \\
\hline 1 & & 253 & 253 & & 21 & & 253 & 253 & \\
\hline 2 & & & 184 & & 22 & & & 184 & \\
\hline 3 & $30^{*}$ & & & 378 & 23 & $30^{*}$ & & & 378 \\
\hline 4 & & & 253 & & 24 & & & 253 & \\
\hline 5 & & 0 & 0 & & 25 & & 0 & 0 & \\
\hline 6 & $0 *$ & & & 0 & 26 & $0 *$ & & & 0 \\
\hline 7 & & 253 & 253 & & 27 & & 421 & 421 & \\
\hline 8 & & & 184 & & 28 & & & 306 & \\
\hline 9 & $30 *$ & & & 378 & 29 & $50 *$ & & & 630 \\
\hline 10 & & & 253 & & 30 & & & 367 & \\
\hline 11 & & 0 & 0 & & 31 & & 505 & & \\
\hline 12 & $0 *$ & & & 0 & 32 & $60^{*}$ & & & 756 \\
\hline 13 & & 84 & 84 & & 33 & & & 428 & \\
\hline 14 & & & 61 & & 34 & & 589 & & \\
\hline 15 & $10^{*}$ & & & 126 & 35 & $70^{*}$ & & & 882 \\
\hline 16 & & & 84 & & 36 & & & 490 & \\
\hline 17 & & 168 & 168 & & 37 & & 674 & & \\
\hline 18 & & & 122 & & 38 & $80^{*}$ & & & 1008 \\
\hline 19 & $20 *$ & & & 253 & 39 & & & 551 & \\
\hline Record Instrumentation & & & & & & & \\
\hline
\end{tabular}


Table 2. Alternate Phase 1 Structural Test Loading Schedule (continued)

\begin{tabular}{|c|c|c|c|c||c|c|c|c|c|}
\hline \multirow{2}{*}{ Step } & Load & $P_{1}=P_{2}$ & $P_{3}$ & $P_{4}$ & \multirow{2}{*}{ Step } & Load & $P_{1}=P_{2}$ & $P_{3}$ & $P_{4}$ \\
\cline { 5 - 10 } & $\%$ & psig & psig & psig & \% & psig & psig & psig \\
\hline 40 & & 756 & & & 47 & $110^{*}$ & & & 1386 \\
\hline 41 & $90^{*}$ & & & 1134 & 48 & & & 704 & \\
\hline 42 & & & 612 & & 49 & & 969 & & \\
\hline 43 & & 842 & & & 50 & $115^{*}$ & & & 1149 \\
\hline 44 & $100^{*}$ & & & 1260 & 51 & & 704 & & \\
\hline 45 & & & 673 & & 52 & & 0 & 0 & \\
\hline 46 & & 926 & & & 53 & 0 & 0 & 0 & 0 \\
\hline
\end{tabular}

Table 3. Phase 2 Structural Proof Test Loading Schedule

\begin{tabular}{|c|c|c|c|c|c|c|c|c|c|c|c|}
\hline \multirow[b]{2}{*}{ Step } & Load & $\mathrm{Pl}$ & $P_{2}$ & $P_{3}$ & $\mathrm{P}_{4}$ & \multirow[b]{2}{*}{ Step } & \multirow{2}{*}{$\frac{\text { Load }}{\%}$} & \multirow{2}{*}{$\frac{P_{1}}{p s i g}$} & \multirow{2}{*}{$\frac{\mathrm{P}_{2}}{\mathrm{psig}}$} & \multirow{2}{*}{$\frac{P_{3}}{p s i g}$} & \multirow{2}{*}{$\frac{\mathrm{P}_{4}}{\mathrm{psig}}$} \\
\hline & $\%$ & psia & psia & psia & psiq & & & & & & \\
\hline 1 & $0^{*}$ & 0 & 0 & 0 & 0 & 12 & & & & 551 & \\
\hline 2 & & 501 & 501 & 501 & & 13 & & & & & 1134 \\
\hline 3 & & & & 428 & & 14 & & & 716 & & \\
\hline 4 & & 589 & & & & 15 & & 842 & & & \\
\hline 5 & $70 *$ & & & & 882 & 16 & & & & 612 & \\
\hline 6 & & & 573 & & & 17 & $100 *$ & & & & 1260 \\
\hline 7 & & 674 & & & & 18 & & & 704 & & \\
\hline 8 & & & & 490 & & 19 & & 704 & & & \\
\hline 9 & 80 & & & & 1008 & 20 & & & & 704 & \\
\hline 10 & & & 644 & & & 21 & & 0 & 0 & 0 & \\
\hline 11 & & 758 & & & & 22 & $0^{*}$ & & & & 0 \\
\hline
\end{tabular}


Table 4. Alternate Phase 2 Structural Proof Test Loading Schedule

\begin{tabular}{|c|c|c|c|c||c|c|c|c|c|}
\hline \multirow{2}{*}{ Step } & Load & $P_{1}=P_{2}$ & $P_{3}$ & $P_{4}$ & $P_{n}$ & Load & $P_{1}=P_{2}$ & $P_{3}$ & $P_{4}$ \\
\hline & $\%$ & psig & psig & psig & Step & $\%$ & psig & psig & psig \\
\hline 1 & $0 *$ & 0 & 0 & 0 & 7 & & 842 & & \\
\hline 2 & & 589 & 589 & & 8 & $100^{*}$ & & & 1260 \\
\hline 3 & & & 428 & & 9 & & 612 & & \\
\hline 4 & $70^{*}$ & & & 882 & 10 & & 0 & 0 & \\
\hline 5 & & & 589 & & 11 & $0 *$ & & & 0 \\
\hline 6 & & 612 & 612 & & $*$ Record Instrumentation & & \\
\hline
\end{tabular}

\subsection{Phase 3 - Cryogenic Structural Proof Test}

7.4.1 Install thermocouples on the Pressure Vessel at Station 44.5, $180^{\circ}$ apart, and on the Nozzle $180^{\circ}$ apart.

7.4.2 Assemble the vessel with the Structural Chamber, using new Omega and Wave Ring Seals. Install metal Nozzle Skirt Seal in lieu of O-ring noted in Paragraph 7. 1(k). Assemble vessel as described in Paragraphs 7.1 (b), (c), (e), (f), (g), (i), (j), (l), $(m),(n),(0),(p),(r)$, and (s). Plug all instrumentation holes with cryogenic seals.

7.4.3 Transport the Pressure Vessel Assembly to the ACF explosives test site at Sandia Base.

7.4.4 Connect the $\mathrm{LN}_{2}$ fill and pressurization systems to the Pressure Vessel Assembly as shown in Figure 8 and place insulation around vessel.

7.4.5 Fill the Pressure Vessel and Clamp Ring with $\mathrm{LN}_{2}$ until thoroughly chilled. Monitor thermocouples to determine temperature stabilization.

CAUTION: Open all relief valves mounted on the Pressure Vessel during filling procedure to prevent gas pressure buildup.

7.4.6 After temperature stabilization, pressurize $P_{1} P_{2}$ to 400 psig, $P_{3}$ to 350 psig and $P_{4}$ to 400 psig with helium. Visually inspect the assembly for leakage and seal any significant leaks. 


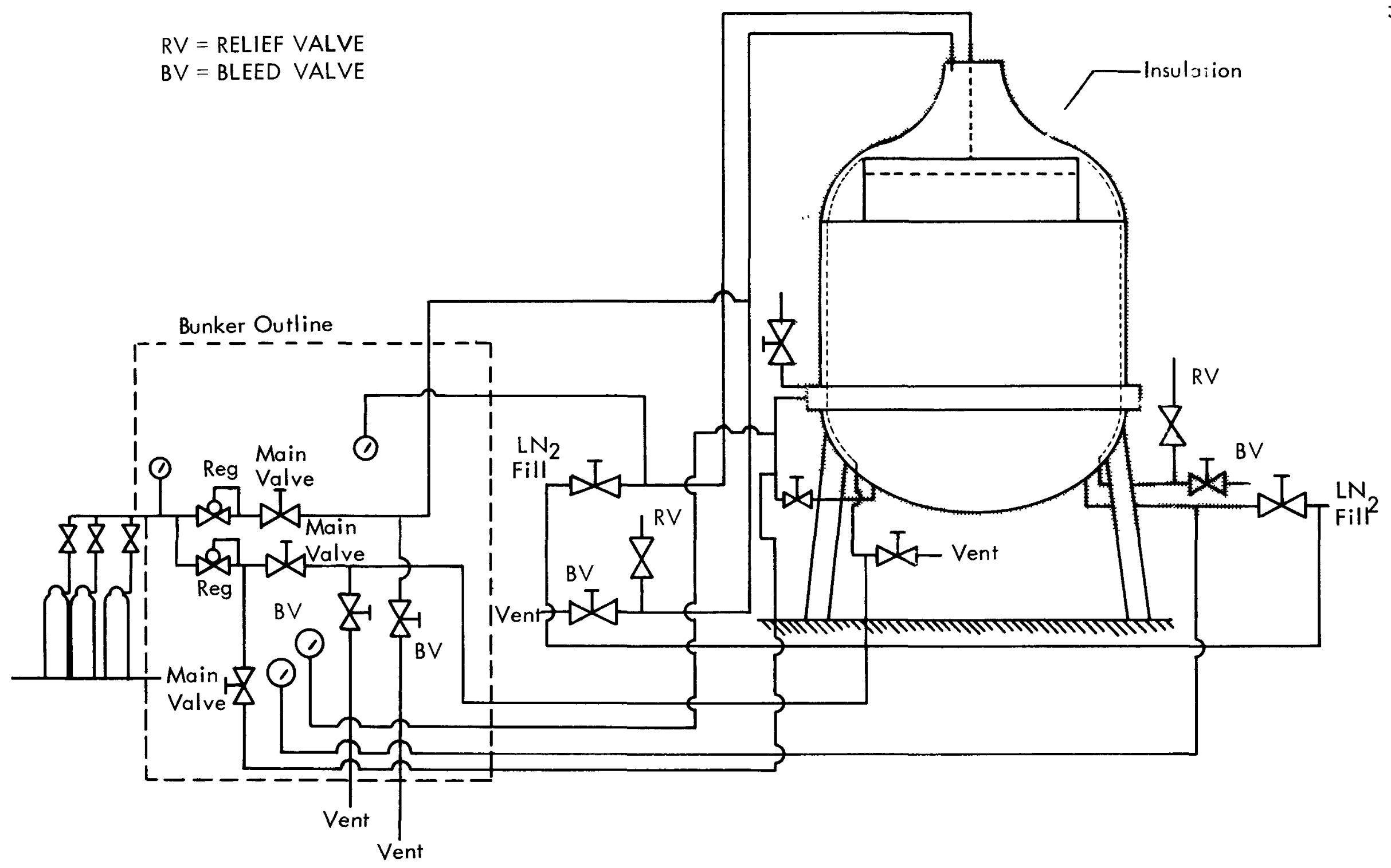

Figure 8. Phoebus $2 \mathrm{CF} / 2 \mathrm{~A}$ Cryogenic Test Setup 
7.4.7 Perform final instrumentation check.

7.4.8 Top off the Pressure Vessel and Clamp Ring with $\mathrm{LN}_{2}$ until thoroughly chilled and boiling of $\mathrm{LN}_{2}$ has ceased. Monitor thermocouples to determine temperature stabilization at $-300^{\circ} \pm 20^{\circ} \mathrm{F}$.

7.4.9 After temperature stabilization, pressurize Pressure Vessel and Clamp Ring per the Phase 3 loading schedule, Table 5 . Record the test data at each pressure increment. Bleed $G N_{2}$ as necessary to maintain as much $L N_{2}$ as possible.

7.4.10 Depressurize Pressure Vessel Assembly and allow it to warm to ambient temperature. Check torque value on 12 nozzle bolts (4 sets of 3 bolts) $90^{\circ}$ apart. Record test data.

7.4.11 Perform the operations specified in Paragraphs 7.4.5 through 7.4.10 for a total of three pressurization cycles. Dye penetrant inspect weld areas after each cycle.

7.4.12 Dissassemble Pressure Vessel Assembly and visually inspect for evidence of deformation. Dye penetrant inspect and $X$-ray weld areas.

Table 5. Cryogenic Proof Test Loading Schedule

\begin{tabular}{|c|c|c|c|}
\hline \multirow{2}{*}{ Step } & \multicolumn{3}{|c|}{ Pressure Vessel and Clamp Ring } \\
Load (psig) \\
\cline { 2 - 4 } & $P_{1}=P_{2}$ & $P_{3}$ & $P_{4}$ \\
\hline 1 & 0 & 0 & 0 \\
\hline 2 & 612 & 612 & 0 \\
\hline 3 & 842 & 612 & 0 \\
\hline 4 & $842^{*}$ & $612^{*}$ & $1260^{*}$ \\
\hline 5 & 612 & 612 & 1260 \\
\hline 6 & 0 & 0 & 1260 \\
\hline 7 & 0 & 0 & 0 \\
\hline $\begin{array}{l}\text { Repeat Steps 1 through 7 for a total of 3 } \\
\text { pressure cycles. }\end{array}$ & \\
\hline $\begin{array}{c}\text { * Pressure maintained for } 5 \text { minutes } a \\
20^{\circ} \mathrm{F}\end{array}$ & & $-300^{\circ} \pm$ \\
\hline
\end{tabular}


BLANK 


\section{REPORT REQUIREMENTS}

8.1 Department 411 (ACF) will issue a preliminary test data report within five working days following completion of each test phase. These reports shall include strain and deflection data as reduced by the ACF IBM D-115 Computer Program and copies of the test log. A formal data report will be issued four weeks after completion of testing. It shall include (1) descriptions of unusual occurrences, (2) miscellaneous information required in this specification, (3) variations from the test specification, (4) strain, stress, deflection, and rotational data graphed as functions of load, and (5) pertinent photographs.

8.2 The Analytical Support Group of Department 431 (ACF) will publish separate test reports within six weeks after completion of testing. The reports shall contain a complete evaluation of the Pressure Vessel Main Closure performance based on a comparison with hydrostatic proof test conditions to the Phoebus 2 redesigned main closure analysis. 
BLANK 
Appendix A

INSTRUMENTATION LIST 
INSTRUMENTATION LIST

\section{GAGE MEASUREMENT \\ NO DESCRIPTION}

MEASUREMENT

LOCATION
MEASUREMENT

RANGE ( $\mu$ IN/IN)
B2 AXIAL STRAIN

B3 AXIAL STRAIN

B4 AXIAL STRAIN

B5 AXIAL STRAIN

B6 AXIAL STRAIN

B7 AXIAL STRAIN

B8 AXIAL STRAIN

B9 AXIAL STRAIN

BIO AXIAL STRAIN

BII AXIAL STRAIN

B1) AXIAL STRAIN

B13 AXIAL STRAIN

B14 AXIAL STRAIN

BI5 AXIAL STRAIN

B16 AXIAL STRAIN

1 :IRI. STRAIN

2 AXIAL STRAIW

3 IR:. STRAIN

$4 \quad A \times I A L$ STRAIN

5 :IR:. STRAIN

6 AXIAL STRAIN

7 :IRL. STRAIN

8 AXIAL STRAIN

9 : IRI. STRAIN
NOZZLE BOLT 1

NO ZZLE BOLT 1

NOZZLE BOLT 1

NOZZLE BOLT I

W ZZLE BOLT 2

NOZZLE BOLT 2

NOZZLE BOLT 2

NO ZZLE BOLT 2

NO ZZLE BOLT 3

NOZZLE BOLT 3

NO ZZLE BOLT 3

NO ZZLE BOLT 3

NOZZLE BOLT 4

NOZZLE BOLT 4

NOZZLE BOLT 4

NOZZLE BOLT 4

DOME OUTSINE STA 0.438

DOME RUTSIDE STA

DJME DUTSIDE STA

DOME OUTSIDE STA

2.375

VESSEL DUTSIDE STA

VESSEL OUTSIDE STA

VESSEL DUTSIDE STA 23.000

VESSEL DUTSIDE STA 23.000

VESSEL INSIDE STA 23.000
O DEGREE O TO 5000

90 DEGREE O TO 5000

180 DEGREE O TO 5000

270 DEGREE 0 TO 5000

D DEGREE O TO 5000

90 DEGREE O TO 5000

180 DEGREE 0 TO 5000

270 DEGREE O TO 5000

O DEGREE O TO 5000

90 DEGREE O TO 5000

180 DEGREE 0 TO 5000

270 DEGREE 0 TO 5000

O DEGREE O TO 5000

90 DEGREE O TO 5000

180 DEGREE O TO 5000

270 DEGREE O TO 5000

90 DEGREE O TO 5000

90 DEGREE O TO 5000

90 DEGREE O TO 5000

90 DEGREE O TO 5000

90 DEGREE O TO 5000

90 DEGREE O TO 5000

90 DEGREE O TO 5000

90 DEGREE O TO 5000

90 DEGREE O TO 5000 
INSTRUMENTATION LIST

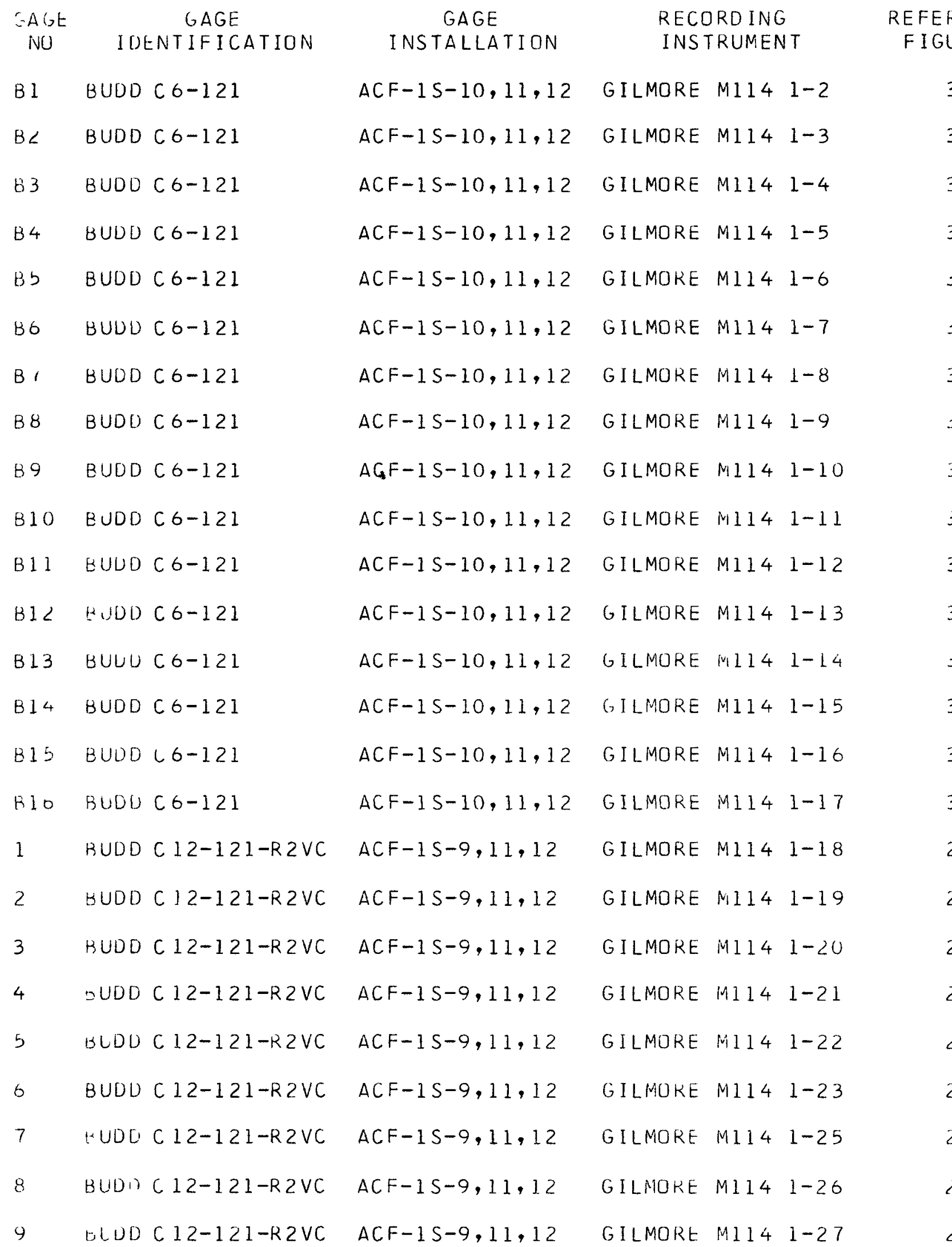

RFERENCE IGURE 
INSTRUMENTATION LIST

GAGE NEASUREMENT

NI DESTRIPTION

IC AXIAL STRAIN

11 ;IRE. STRAIN

$12 A$ AAL STRAIN

13 ? IR: . STRAIN

14 AXIAL STRAIN

IS IRj. STRAIN

16 AXIAL STRAIN

17 IR: STRAIN

18 AXIAL STRAIN

19 IR: . STRAIN

20 AXIAL STRAIN

21 IR: . STRAIN

22 AXIAL STRAIN

23 IRL . STRAIN

24 AXIAL STRAIN

$25:$ IR: - STRAIN

26 DIAG. STRAIN

27 AXIAL STRAIN

$28:$ IRJ. STRAIN

29 DIAG. STRAIN

30 AXIAL STRAIN

$31: I R J \cdot$ STRAIN

32 DIAG. STRAIN

33 AXTAL STRAIN

$34 ., 1 \%$ STRAIN
MEASUREMENT

LOCAT ION!

VFSSEL INSIDE STA 23.000 VESSEL OUTSIDE STA 50.500

VESSEL DUTSIDE STA 50.500

VESSEL INSIDE STA 50.500

VESSEL INSIDE

STA 50.500

90 DEGREE

MEASUREMENT

RANGE $(\mu I N / I N)$

VESSEL INSIDE STA $9.62590 \quad$ DEGREE O TO 5000

VESSEL INSIDE STA $9.625 \quad 90 \quad$ DEGREE O TO 5000

VESSEL INSIDE STA $7.912 \quad 90$ DEGREE 0 TO 5000

VESSEL INSIDE STA 7.91290 DEGREE O TO 5000

DOME INSIDE STA $4.088 \quad 90 \quad$ DEGREE O TO 5000

DOME INSIDE STA 4.08890 DEGREE 0 TO 5000

DOME INSIDE STA $2.375 \quad 90 \quad$ DEGREE O TO 5000

DOME INSIDE STA $2.375 \quad 90 \quad$ DEGREE O TO 5000

DOME INSIDE STA 0.438 90 DEGREE O TO 5000

DOME INSIDE STA $0.438 \quad 90$ DEGREE O TO 5000

CLAMP SEGMENT BOT CORNER

0 TO 5000

CLAMP SEGMENT BOT CORNER

CLAMP SEGMENT BOT CORNER

CLAMP SEGMENT TOP CORNER

CLAMP SEGMENT TOP CORNER

CLAMP SEGMENT TOP CORNER

CLAMP SEgMENT CENTER

CLAMP SEGMENT CFNTER

CLAMP SFGMENT CENTFR

DOME OUTSIDE STA 0.438
105 DEGREE O TO 5000

105 DEGREE O T(1 $50(0)$

105 DEGKEE O TO 5000

O TO 5000

O TO 5000

O TO 5000

0 TO 5000

0 TO 5000

270 DEGREE O TO 5000 
INSTRUMENTATION LIST

\begin{tabular}{|c|c|c|c|c|c|}
\hline $\begin{array}{l}\text { GAGE } \\
\text { NO }\end{array}$ & $\begin{array}{c}\text { GAGE } \\
\text { IDENTIFICATION }\end{array}$ & $\begin{array}{c}\text { GAGE } \\
\text { INSTALLATION }\end{array}$ & $\begin{array}{l}\text { RECL } \\
\text { INS }\end{array}$ & $\begin{array}{l}\text { TRD ING } \\
\text { TRUMENT }\end{array}$ & $\begin{array}{l}\text { REFERENCE } \\
\text { FIGURE }\end{array}$ \\
\hline 10 & BUDD C $12-121-R 2 V C$ & $A C F-1 S-9,11,12$ & GILMORE & $\operatorname{MI14} \quad 1-28$ & 2 \\
\hline 11 & BUDD C 12-121-R 2 VC & $A C F-15-9,11,12$ & GILMORE & $M 114 \quad 1-29$ & 2 \\
\hline 12 & BUDD C $12-121-R 2 V C$ & $A C F-1 S-9,11,12$ & GILMORE & $M 114 \quad 1-30$ & 2 \\
\hline 13 & BUDD C 12-121-R2VC & $A C F-1 S-9,11,12$ & GILMORE & $M 114 \quad 1-31$ & 2 \\
\hline 14 & BUDO C 12-121-R2VC & $A C F-1 S-9,11,12$ & GILMORE & $M 1141-32$ & 2 \\
\hline 15 & BUDD C $12-121-R 2$ VC & $A C F-1 S-9,11,12$ & GILMORE & $M 114 \quad 1-33$ & 2 \\
\hline 16 & BUDD C $12-121-R 2 V C$ & $A C F-1 S-9,11,12$ & GILMORE & $M 114 \quad 1-34$ & 2 \\
\hline 17 & BUDD C 12-121-R 2VC & $A C F-1 S-9,11,12$ & GILMORE & $M 114 \quad 1-35$ & 2 \\
\hline 18 & BUDD C 12-121-R2VC & $A C F-1 S-9,11,12$ & GILMORE & $M 114 \quad 1-36$ & 2 \\
\hline 19 & BUDD C 12-121-R2VC & $A C F-1 S-9,11,12$ & GILMORE & M114 $1-37$ & 2 \\
\hline 20 & BUDD C $12-121-R 2 V C$ & $A C F-1 S-9,11,12$ & GILMORE & $\operatorname{M114} 1-38$ & 2 \\
\hline 21 & BUDD C $12-121-R 2 V C$ & $A C F-1 S-9,11,12$ & GILMORE & $M 114 \quad 1-39$ & 2 \\
\hline 22 & BUDD C $12-121-R 2$ VC & $A C F-15-9,11,12$ & GILMORE & $M 114 \quad 1-40$ & 2 \\
\hline 23 & BUDD C 12-121-R2VC & $A C F-1 S-9,11,12$ & GILMORE & $\operatorname{Ml1} 4 \quad 1-41$ & 2 \\
\hline 24 & BUDD C $12-121-R 2$ VC & $A C F-1 S-9,11,12$ & GILMORE & $M 114 \quad 1-42$ & 2 \\
\hline 25 & BUDD EC 12-121-R3TS & $A C F-1 S-9,11,12$ & GILMORE & $M 114 \quad 1-43$ & 2 \\
\hline 26 & BUDD EC 12-121-R3TS & $A C F-1 S-9,11,12$ & GILMORE & $M 114 \quad 1-44$ & 2 \\
\hline 27 & BUDD EC 12-121-R3TS & $A C F-1 S-9,11,12$ & GILMORE & $M 114 \quad 1-45$ & 2 \\
\hline 28 & BUDD EC 12-121-R3TS & $A C F-1 S-9,11,12$ & GILMORE & $M 114 \quad 1-46$ & 2 \\
\hline 29 & BUDD EC 12-121-R3TS & $A C F-1 S-9,11,12$ & GILMORE & $M 114 \quad 1-47$ & 2 \\
\hline 30 & BUDD EC 12-121-R3TS & $A C F-1 S-9,11,12$ & GILMORE & $M 114 \quad 1-49$ & 2 \\
\hline 31 & BUDD EC $12-121-R 3 T S$ & $A C F-1 S-9,11,12$ & GILMORE & $M 114 \quad 1-50$ & 4 \\
\hline 32 & BUDD EC 12-121-R3TS & $A C F-1 S-9,11,12$ & GILMORE & $M 114 \quad 1-51$ & 4 \\
\hline 33 & BUDD EC 12-121-R3TS & $A C F-1 S-9,11,12$ & GILMORE & $M 1141-52$ & 4 \\
\hline 34 & BUDD C 12-121-R2VC & $A C F-1 S-9,11,12$ & GILMORE & $M 1141-53$ & 2 \\
\hline
\end{tabular}


INSTRUMENTATION LIST

GAGE MEASUREMENT

NO DESCRIPTION

35 AXIAL STRAIN

36 CIRC . STRAIN

37 AXIAL STRAIN

38 CIRC . STRAIN

39 AXIAL STRAIN

40 CIRC. STRAIN

41 AXIAL STRAIN

42 CIRC. STRAIN

43 AXIAL STRAIN

44 CIRC. STRAIN

45 AXIAL STRAIN

46 CIRC. STRAIN

47 AXIAL STRAIN

48 CIRC. STRAIN

49 AXIAL STRAIN

50 CIRC. STRAIN

51 AXIAL STRAIN

52 CIRC. STRAIN

53 AXIAL STRAIN

54 CIRC . STRAIN

55 AXIAL STRAIN

56 CIRC. STRAIN

57 AXIAL STRAIN

58 CIRC. STRAIN

59 DIAG. STRAIN
MEASUREMENT

LOCATION

DOME OUTSIDE STA 0.438

DOME OUTSIDE STA 2.375

DOME OUTSIDE STA 2.375

VESSEL DUTSIDE STA 9.625

VESSEL OUTSIDE STA 9.625

VESSEL DUTSIDE STA 23.000

VESSEL OUTSIDE STA 23.000

VESSEL INSIDE STA 23.000

VESSEL INSIDE STA 23.000

VESSEL OUTSIDE STA 50.000

VESSEL DUTSIDE STA 50.000

VESSEL INSIDE STA 50.000

VESSEL INSIDE STA 50.000

270 DEGREE

MEASUREMENT

RANGE $(\mu I N / I N)$
VESSEL INSIDE STA $9.625 \quad 270$ DEGREE O TO 5000

VESSEL INSIDE STA $9.625 \quad 270$ DEGREE O TO 5000

VESSEL INSIDE STA $7.912 \quad 270$ DEGREE 0 TO 5000

VESSEL INSIDE STA $7.912 \quad 270$ DEGREE O TO 5000

DOME INSIDE STA $4.088 \quad 270$ DEGREE O TO 5000

DOME INSIDE STA $4.088 \quad 270$ DEGREE 0 TO 5000

DOME INSIDE STA $2.375 \quad 270$ DEGREE O TO 5000

DOME INSIDE STA $2.375 \quad 270$ DEGREE O TO 5000

DOME INSIDE STA $0.438 \quad 270$ DEGREE O TO 5000

DOME INSIDE STA $0.438 \quad 270$ DEGREE 0 TO 5000

CLAMP SEgMENT BOT CORNER 120 DEGREE O TO 5000 CLAMP SEGMENT BOT CORNER 120 DEGREE 0 TO 5000 
INS TRUMENTATION LIST

GAGE
NO

GAGE
IDENTIFICATION
RECORDING INS TRUMENT
REFERENCE FIGURE

2 2 2 2 2 2 2 2 2 2 2 2 2 2 2 2 2 2 2 2 2 2 2 2 2 
INSTRUMENTATION LIST

GAGE MEASUREMENT

NO DESCRIPTION

60 AXIAL STRAIN

61 CIRE . STRAIN

62 DIAG. STRAIN

63 AXIAL STRAIN

64 CIRC . STRAIN

65 DIAG. STRAIN

66 AXIAL STRAIN

67 CIRC - STRAIN

68 AXIAL STRAIN

69 CIRC . STRAIN

70 AXIAL STRAIN

71 CIRC . STRAIN

72 AXIAL STRAIN

73 C IRC - STRAIN

74 AXIAL STRAIN

75 CIRC . STRAIN

76 CIRC - STRAIN

77 CIRC - STRAIN

78 C IRC - STRAIN

79 CIRC - STRAIN

80 CIRC . STRAIN

81 CIRC . STRAIN

82 CIRC - STRAIN

83 C IRE - STRAIN

84 C IRC - STRAIN
MEASUREMENT

LOCATION
MEASUREMENT

RANGE ( $\mu I N / I N)$

CLAMP SEGMENT BOT CORNER 120 DEGREE 0 TO 5000

CLAMP SEGMENT TOP CORNER 120 DEGREE 0 TO 5000

CLAMP SEGMENT TOP CORNER 120 DEGREE 0 TO 5000

CLAMP SEGMENT TOP CORNER 120 DEGREE 0 TO 5000

CLAMP SEGMENT CENTER

275 DEGREE 0 TO 5000

CLAMP SEGMENT CENTER

275 DEGREE 0 TO 5000

CLAMP SEGMENT CENTER

275 DEGREE O TO 5000

CLAMP RING

STA 3.800

95 DEGREE 0 TO 5000

CLAMP RING

STA 3.800

95 DEGREE O TO 5000

CLAMP RING

STA 8.200

95 DEGREE O TO 5000

CLAMP RING

STA 8.200

95 DEGREE O TO 5000

CLAMP RING

STA $3.800 \quad 275$ DEGREE O TO 5000

CLAMP RING

STA $3.800 \quad 275$ DEGREE 0 TO 5000

CLAMP RING

STA $8.200 \quad 275$ DEGREE O TO 5000

CLAMP RING

STA $8.200 \quad 275$ DEGREE 0 TO 5000

CLAMP RING

STA $3.700 \quad 45$ DEGREE 0 TO 5000

CLAMP RING

STA 3.700

135 DEGREE 0 TO 5000

CLAMP RING

STA 3.700

225 DEGREE 0 TO 5000

CLAMP RING

STA 3.700

315 DEGREE O TO 5000

CLAMP RING

STA $6.000 \quad 45$ DEGREE 0 TO 5000

CLAMP RING

STA $6.000 \quad 225$ DEGREE 0 TO 5000

CLAMP RING

STA 8.300

315 DEGREE 0 TO 5000

CLAMP RING

STA 8.300

225 DEGREE 0 TO 5000

CLAMP RING

STA 8.300

135 DEGREE O TO 5000

CLAMP RING

STA 8.300 
INSTRUMENTATION LIST

\begin{tabular}{|c|c|c|c|c|c|}
\hline $\begin{array}{l}\text { GAGE } \\
\text { NO }\end{array}$ & $\begin{array}{c}\text { GAGE } \\
\text { IDENTIFICATION }\end{array}$ & $\begin{array}{c}\text { GAGE } \\
\text { INSTALLATION }\end{array}$ & $\begin{array}{l}\text { RECD } \\
\text { INST }\end{array}$ & $\begin{array}{l}\text { RDD ING } \\
\text { TRUMENT }\end{array}$ & $\begin{array}{l}\text { REFERENCE } \\
\text { FIGURE }\end{array}$ \\
\hline 60 & BUDD EC 12-121-R3TS & $A C F-1 S-9,11,12$ & G I LMORE & $M 114 \quad 1-80$ & 2 \\
\hline 61 & BUDD EC 12-121-R3TS & $A C F-1 S-9,11,12$ & GILMORE & $M 1141-81$ & 2 \\
\hline 62 & BUDD EC 12-121-R3TS & $A C F-1 S-9,11,12$ & GILMORE & $M 114 \quad 1-82$ & 2 \\
\hline 63 & BUUD EC 12-121-R3TS & $A C F-1 S-9,11,12$ & G ILMORE & $M 114 \quad 1-83$ & 2 \\
\hline 64 & BUDD EC 12-121-R3TS & $A C F-1 S-9,11,12$ & GILMORE & $M 114 \quad 1-84$ & 2 \\
\hline 65 & BUDD EC 12-121-R3TS & $A C F-1 S-9,11,12$ & GILMORE & $M 114 \quad 1-85$ & 2 \\
\hline 66 & BUDD EC 12-121-R3TS & $A C F-1 S-9,11,12$ & GILMORE & $M 114 \quad 1-86$ & 2 \\
\hline 67 & BUDD C 12-12I-R2VC & $A C F-1 S-9,11,12$ & GILMORE & $M 114 \quad 1-87$ & 2 \\
\hline 68 & BUDD C 12-121-R2VC & $A C F-1 S-9,11,12$ & GILMORE & $M 114 \quad 1-88$ & 2 \\
\hline 69 & BUDD C 12-121-R2VC & $A C F-1 S-9,11,12$ & GILMORE & $\operatorname{M114} 1-89$ & 2 \\
\hline 70 & BUDD C 12-121-R 2 VC & $A C F-1 S-9,11,12$ & GILMORE & $M 114 \quad 1-90$ & 2 \\
\hline 71 & BUDOC 12-121-R2VC & $A C F-1 S-9,11,12$ & GILMORE & $\operatorname{M114} 1-91$ & 2 \\
\hline 72 & BUDD C 12-121-R 2 VC & $A C F-1 S-9,11,12$ & G ILMORE & $M 114 \quad 1-92$ & 2 \\
\hline 73 & $B \cup D D C 12-121-R 2 V C$ & $A C F-1 S-9,11,12$ & GILMORE & $M 114 \quad 1-93$ & 2 \\
\hline 74 & $B \cup D D C 12-121-R 2 V C$ & $A C F-1 S-9,11,12$ & GILMORE & $M 114 \quad 1-94$ & 2 \\
\hline 75 & $B L H \quad P A-18$ & SR-4 CEMENT & G I LMORE & $M 114 \quad 2-73$ & 2 \\
\hline 76 & BLH PA-18 & SR-4 CEMENT & GILMORE & $M 114 \quad 2-74$ & 2 \\
\hline 77 & BLH PA-18 & SR-4 CEMENT & GILMORE & $M 114 \quad 2-75$ & 2 \\
\hline 78 & BLH PA-18 & SR -4 CEMENT & G ILMORE & $M 114 \quad 2-76$ & 2 \\
\hline 79 & BLH PA-18 & SR -4 CEMENT & GILMORE & $M 1142-77$ & 2 \\
\hline 80 & BLH PA-18 & SR -4 CEMENT & GILMORE & $M 1142-78$ & 2 \\
\hline 81 & $B L H$ PA-18 & SR-4 CEMENT & G I LMORE & $M 114 \quad 2-79$ & 2 \\
\hline 82 & BLH PA-18 & SR-4 CEMENT & G I LMORE & $\operatorname{M114} 2-80$ & .2 \\
\hline 83 & BLH PA-18 & SR -4 CEMENT & G I LMORE & $M 1142-81$ & 2 \\
\hline 84 & $B L H \quad P A-18$ & SR -4 CEMENT & GILMORE & $M 114 \quad 2-82$ & 2 \\
\hline
\end{tabular}


INSTRUMENTATION LIST

\begin{abstract}
GAGE MEASUREMENT NO DESCRIPTION
\end{abstract}

85 CIRC. STRAIN

86 AXIAL STRAIN

87 RADIAL DEF.

88 RADIAL DEF.

89 RADIAL DEF.

90 RADIAL DEF.

91 RADIAL DEF.

92 RADIAL DEF.

93 RADIAL DEF.

94 RADIAL DEF.

95 RADIAL DEF.

96 RADIAL DEF.

97 RADIAL DEF.

98 RADIAL DEF.

99 RADIAL DEF.

100 RAUIAL DEF.

101 RADIAL DEF.

102 RADIAL DEF.

103 RADIAL DEF.

104 RADIAL DEF.

105 RADIAL DEF.

106 RADIAL DEF.

107 RADIAL DEF.

108 RADIAL DEF.

109 GAP SEPARATION
MEASUREMENT

LOCATION
MEASUREMENT

RANGE ( $\mu$ IN/IN)
DOME SHEAR LIP STA 6.00090 DEGREE 0 TO 5000 DOME SHEAR LIP STA $6.000 \quad 90$ DEGREE 0 TO 5000 DOME FLANGE BOTTOM

DOME FLANGE TOP

BOT CLAMP SEG. BOTTOM

BOT CLAMP SEG. TOP

CLAMP RING

BOTTOM

CLAMP RING

CENTER

CLAMP RING

TOP

TOP CLAMP SEG. BOTTOM

TOP CLAMP SEG. TOP

VESSEL FLANGE BOTTOM

VESSEL FLANGE TOP

DOME FLANGE BOTTOM

DOME FLANGE TOP

BOT CLAMP SEg. BOTTOM

BOT CLAMP SEG. TOP

CLAMP RING BOTTOM

CLAMP RING CENTER

CLAMP RING TOP

TOP CLAMP SEG. BOTTOM

TOP CLAMP SEG. TOP

VESSEL flange BOtTOM

VESSEL FLANGE TOP

INSIDE VESSEL TO DOME
O DEGREE O TO 2000

O DEGREE O TO 2000

O DEGREE O TO 2000

O DEGREE O TO 2000

O DEGREE O TO 2000

O DEGREE 0 TO 2000

O DEGREE O TO 2000

O DEGREE 0 TO 2000

O DEGREE O TO 2000

O DEGREE 0 TO 2000

O DEGREE 0 TO 2000

180 DEGREE 0 TO 2000

180 DEGREE 0 TO 2000

180 DEGREE 0 TO 2000

180 DEGREE O TO 2000

180 DEGREE 0 TO 2000

180 DEGREE O TO 2000

180 DEGREE 0 TO 2000

180 DEGREE O TO 2000

180 DEGREE O TO 2000

180 DEGREE O TO 2000

180 DEGREE O TO 2000

30 DEGREE 0 TO 2000 


\section{INS TRUMENTAT ION LIST}

\begin{tabular}{|c|c|c|c|c|c|c|c|c|}
\hline $\begin{array}{l}G \wedge G E \\
N D\end{array}$ & & $\begin{array}{r}\text { GA } \\
\text { ENTIF }\end{array}$ & $\begin{array}{l}\text { AGE } \\
\text { FICATION }\end{array}$ & $\begin{array}{c}\text { GAGE } \\
\text { INSTALLATION }\end{array}$ & $\begin{array}{l}\text { RECL } \\
\text { INS }\end{array}$ & $\begin{array}{l}\text { TRD INC } \\
\text { TRUMEN }\end{array}$ & & $\begin{array}{l}\text { REFERENC: } \\
\text { FIGURE }\end{array}$ \\
\hline 85 & BUDD & $\mathrm{C} 12-$ & $-121-R 2 V C$ & $A C F-1 S-9,11,12$ & GILMORE & $M 114$ & $2-83$ & 2 \\
\hline 86 & BUDD & $\mathrm{C} 12-$ & $-12 I-R 2 V C$ & $A C F-1 S-9,11,12$ & GILMORE & M114 & $2-84$ & 2 \\
\hline 87 & $A C F$ & TYPE & $\mathrm{C}$ & & G I LMORE & $M 114$ & $2-41$ & 6 \\
\hline 88 & $A C F$ & TYPE & $\mathrm{C}$ & & GILMORE & M114 & $2-42$ & 6 \\
\hline 89 & $A C F$ & TYPE & $\mathrm{C}$ & & GILMORE & MI1 14 & $2-43$ & 6 \\
\hline 90 & $A C F$ & TYPE & C & & G I LMORE & Mll 4 & $2-44$ & 6 \\
\hline 91 & $A C F$ & TYPE & C & & GILMORE & M114 & $2-45$ & 6 \\
\hline 92 & $A C F$ & TYPE & $\mathrm{C}$ & & GILMORE & $M 114$ & $2-46$ & 6 \\
\hline 93 & $A C F$ & TYPE & $\mathrm{C}$ & & GILMORE & M114 & $2-47$ & 6 \\
\hline 94 & $A C F$ & TYPE & $C$ & & GILMORE & M114 & $2-49$ & 6 \\
\hline 95 & $A C F$ & TYPE & $c$ & & GILMORE & M114 & $2-50$ & 6 \\
\hline 96 & $A C F$ & TYPE & $C$ & & GILMORE & $M 114$ & $2-51$ & 6 \\
\hline 97 & $A C F$ & TYPE & $C$ & & G I LMORE & $M 114$ & $2-52$ & 6 \\
\hline 98 & $A C F$ & TYPE & $C$ & & GILMORE & M114 & $2-53$ & 6 \\
\hline 99 & $A C F$ & TYPE & $C$ & & G I LMORE & $M 114$ & $2-54$ & 6 \\
\hline 100 & $A C F$ & TYPE & $c$ & & G I LMORE & $M 114$ & $2-55$ & 6 \\
\hline 101 & $A C F$ & TYPE & $C$ & & GILMORE & $M 114$ & $2-56$ & 6 \\
\hline 102 & $A C F$ & TYPE & $C$ & & GILMORE & $\operatorname{Mll} 4$ & $2-57$ & 6 \\
\hline 103 & $A C F$ & TYPE & $C$ & & GILMORE & $\operatorname{MII} 4$ & $2-58$ & 6 \\
\hline 104 & $A C F$ & TYPE & $C$ & & GILMORE & M114 & $2-59$ & 6 \\
\hline 105 & $A C F$ & TYPE & $C$ & & GILMORE & M114 & $2-60$ & 6 \\
\hline 106 & $A C F$ & TYPE & $C$ & & G I LMORE & M114 & $2-61$ & 6 \\
\hline 107 & $A C F$ & TYPE & $C$ & & GILMORE & M114 & $2-62$ & 6 \\
\hline 108 & $A C F$ & TYPE & $C$ & & GILMORE & $M 114$ & $2-63$ & 6 \\
\hline 109 & $A C F$ & T YPE & $C$ & & GILMORE & $M 114$ & $2-64$ & 6 \\
\hline
\end{tabular}


INSTRUMENTATION LIST

GAGE MEASUREMENT

NO DESCRIPTION
MEASUREMENT

LOCATION
MEASUREMENT

RANGE ( $I$ IN/IN)
110 GAP SEPARATION OUTSIDE VESSEL TO DOME

111 GAP SEPARATION INSIDE VESSEL TO DOME

112 GAP SEPARATION DUTSIDE VESSEL TO DOME

113 VESSEL ROT.

NOZZEL-VESSEL INTERFACE

114 NOZZLE ROT. NOZZEL-VESSEL INTERFACE

115 VESSEL ROT. NOZZEL-VESSEL INTERFACE

116 NO-ZZLE ROT. NOZZEL-VESSEL INTERFACE

117 GAP SEPARATION NOZZEL-VESSEL INTERFACE

118 GAP SEPARATION NOZZEL-VESSEL INTERFACE

119 GAP SEPARATION NOZZEL-VESSEL INTERFACE

120 GAP SEPARATION NOZZEL-VESSEL INTERFACE

121 CIRC . STRAIN

122 AXIAL STRAIN

123 CIRC • STRAIN

124 DIAG. STRAIN

125 AXIAL STRAIN

126 CIRC. STRAIN

127 DIAG. STRAIN

128 AXIAL STRAIN
DOME SHEAR LIP STA 6.000

DOME SHEAR LIP STA 6.000

CLAMP SEGMENT CENTER

Clamp SEgment CENTER

CLAMP SEgMENT CENTER

CLAMP SEGMENT CENTER

Clamp segment Center

CLAMP SEgMENT CENTER
30 DEGREE 0 TO 2000

210 DEGREE 0 TO 2000

210 DEGREE 0 TO 2000

90 DEGREE $0-5$ MIN ARC

90 DEGREE $0-5$ MIN ARC

270 DEGREE $0-5$ MIN ARC

270 DEGREE $0-5$ MIN ARC

- DEGREE 0 TO 2000

90 DEGREE O TO 2000

180 DEGREE 0 TO 2000

270 DEGREE O TO 2000

270 DEGREE O TO 5000

270 DEGREE O TO 5000

98 DEGREE 0 TO 5000

98 DEGREE O TO 5000

98 DEGREE O TO 5000

91 DEGREE O TO 5000

91 DEGREE O TO 5000

91 DEGREE O TO 5000 


\section{INSTR UMENTATION LIST}

\begin{tabular}{|c|c|c|c|c|}
\hline $\begin{array}{l}\text { GAGE } \\
\text { NO }\end{array}$ & $\begin{array}{c}\text { GAGE } \\
\text { IDENTIFICATION }\end{array}$ & $\begin{array}{c}\text { GAGE } \\
\text { INSTALLATION }\end{array}$ & $\begin{array}{l}\text { RECORDING } \\
\text { INSTRUMENT }\end{array}$ & $\begin{array}{l}\text { REFERENCE } \\
\text { FIGURE }\end{array}$ \\
\hline 110 & ACF TYPE C & & GILMORE MI14 2-65 & 6 \\
\hline 111 & $A C F$ TYPE C & & GILMORE M114 2-66 & 6 \\
\hline 112 & ACF TYPE C & & GILMORE MI14 2-67 & 6 \\
\hline 113 & AUTOC OLLIMATOR & & MANUAL RECORDING & 5 \\
\hline 114 & AUTOCOLLIMATOR & & MANUAL RECORDING & 5 \\
\hline 115 & AUTOC OLLIMATOR & & MANUAL RECORDING & 5 \\
\hline 116 & AUTOCOLLIMATOR & & MANUAL RECORDING & 5 \\
\hline 117 & $A C F$ TYPE C & & GILMORE M114 2-68 & 5 \\
\hline 118 & ACF TYPE C & & GILMORE MII4 2-69 & 5 \\
\hline 119 & $A C F$ TYPE $C$ & & GILMORE MII4 2-70 & 5 \\
\hline 120 & $A C F$ TYPE C & & GILMORE MII4 2-71 & 5 \\
\hline 121 & BUDD C 12-121-R 2 VC & $A C F-1 S-9,11,12$ & GILMORE MII4 2-85 & 2 \\
\hline 122 & BUDD C 12-121-R2VC & $A C F-1 S-9,11,12$ & GILMORE MII $2-86$ & 2 \\
\hline 123 & BUDD EC 12-121-R3TS & $A C F-1 S-9,11,12$ & GILMORE MI14 2-87 & 4 \\
\hline 124 & BUDD EC 12-121-R3TS & $A C F-1 S-9,11,12$ & GILMORE MI14 2-88 & 4 \\
\hline 125 & BUDD EC 12-121-R3TS & $A C F-1 S-9,11,12$ & GILMORE MII $42-89$ & 4 \\
\hline 126 & BUDD EC 12-121-R3TS & $A C F-1 S-9,11,12$ & GILMORE MII4 2-90 & 4 \\
\hline 127 & BUDD EC 12-121-R3TS & $A C F-1 S-9,11,12$ & GILMORE MII4 2-91 & 4 \\
\hline 128 & BUDD EC 12-121-R3TS & $A C F-1 S-9,11,12$ & GILMORE MII4 2-92 & 4 \\
\hline
\end{tabular}




\section{BLANK}

